\title{
Geography, Economic Policy and Regional Development in China
}

Sylvie Démurger, Jeffrey D. Sachs, Wing Thye Woo, Shuming Bao, Gene Chang, and Andrew Mellinger

CID Working Paper No. 77

October 2001

(C) Copyright 2001 Sylvie Démurger, Jeffrey D. Sachs, Wing Thye Woo, Shuming Bao, Gene Chang, and Andrew Mellinger and the President and Fellows of Harvard College
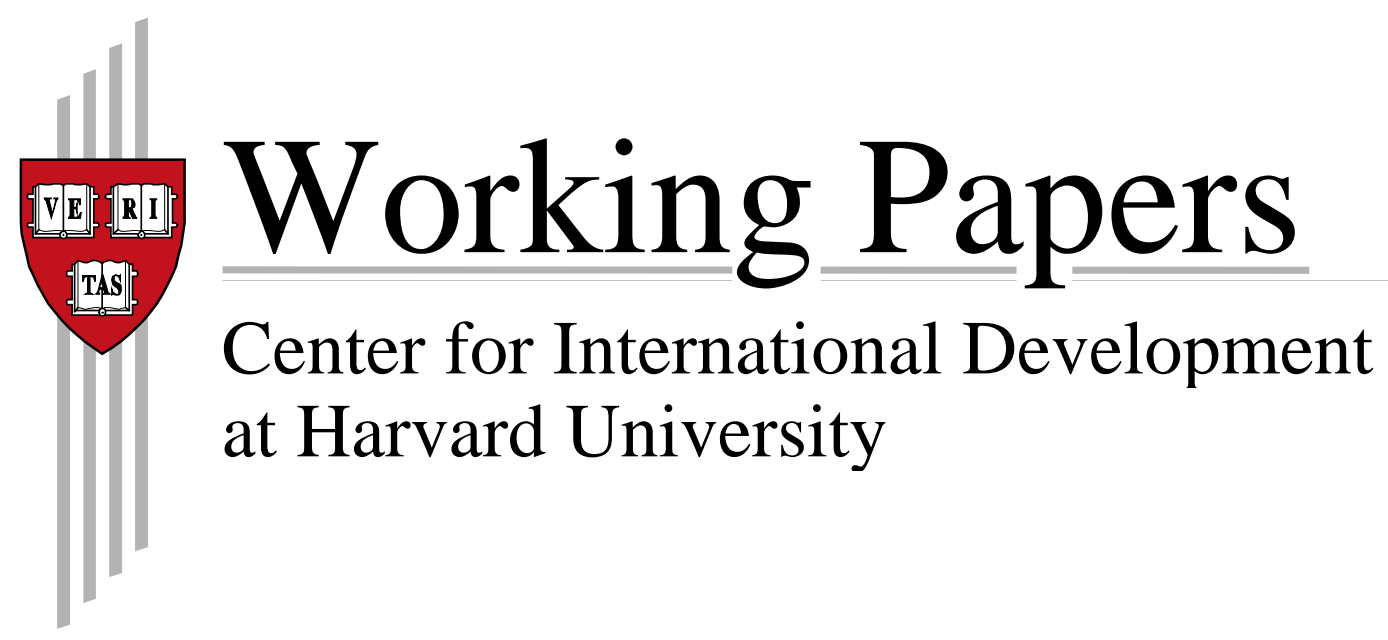
Forthcoming in Asian Economic Papers Vol. 1 No. 1

\title{
Geography, Economic Policy and Regional Development in China
}

\author{
Sylvie Démurger \\ Centre National de la Recherche Scientifique (CNRS) \\ Centre d'Etudes et de Recherches sur le Développement International (CERDI) \\ s.demurger@u-clermont1.fr \\ Jeffrey D. Sachs \\ Center for International Development (CID) \\ Harvard University \\ jeffrey-sachs@harvard.edu \\ Wing Thye Woo \\ Economics Department \\ University of California, Davis \\ wtwoo@ucdavis.edu \\ Shuming Bao \\ China Data Center \\ University of Michigan \\ sbao@umich.edu \\ Gene Chang \\ Economics Department \\ University of Toledo \\ gchang3@uoft02.utoledo.edu \\ Andrew Mellinger \\ Center for International Development \\ Harvard University \\ andrew_mellinger@harvard.edu \\ October 14, 2001 Revision
}

This paper benefited tremendously from the comments of the participants at the following meetings: the inaugural meeting of the Asian Economic Panel, held 26-27 April 2001 in Cambridge, Massachusetts; the Third International Conference on the Chinese Economy, "Has China become a Market Economy?" held 17-18 May 2001 at CERDI, Clermont-Ferrand, France; the symposium on "The Opportunities and Challenges of China's WTO Accession," held 28-29 May 2001 at the State Development Planning Commission, Beijing, China; the International Conference on "Urbanization in China: Challenges and Strategies of Growth and Development," held 27-28 June 2001 at Xiamen University, China; and the Development Workshop of the Research School of Pacific and Asian Studies, Australia National University, Canberra, Australia. We are especially grateful to Fan Gang, Wang Xiaolu, Richard Wong, Thierry Pairault, Du Ping, Shunfeng Song, Ligang Song, Wei Men, Prema-Chandra Athukorala, and Peter Drysdale for many detailed suggestions. 
October 14, 2001

\title{
Geography, Economic Policy and Regional Development in China
}

\author{
Sylvie Démurger, Jeffrey D. Sachs, Wing Thye Woo, Shuming Bao, \\ Gene Chang and Andrew Mellinger
}

\begin{abstract}
Many studies of regional disparity in China have focused on the preferential policies received by the coastal provinces. We decomposed the location dummies in provincial growth regressions to obtain estimates of the effects of geography and policy on provincial growth rates in 1996-99. Their respective contributions in percentage points were 2.5 and 3.5 for the province-level metropolises, 0.6 and 2.3 for the northeastern provinces, 2.8 and 2.8 for the coastal provinces, 2.0 and 1.6 for the central provinces, 0 and 1.6 for the northwestern provinces, and 0.1 and 1.8 for the southwestern provinces. Because the so-called preferential policies are largely deregulation policies that allowed coastal Chinese provinces to integrate into the international economy, it is far superior to reduce regional disparity by extending these deregulation policies to the interior provinces than by re-regulating the coastal provinces. Two additional inhibitions to income convergence are the household registration system, which makes the movement of the rural poor to prosperous areas illegal, and the monopoly state bank system that, because of their bureaucratic nature, disburses most of its funds to its large traditional customers, few of whom are located in the western provinces. Improving infrastructure to overcome geographic barriers is fundamental to increasing western growth, but increasing human capital formation (education and medical care) is also crucial because only it can come up with new better ideas to solve centuries-old problems like unbalanced growth.
\end{abstract}

JEL Categories: D300, O180, O530, P250, P520, R110, R120

Keywords: China's Regional Growth Pattern, Economic Geography, Preferential Policies, China's Western Region Development Strategy

Corresponding author:

Wing Thye Woo Economics Department

University of California

One Shields Avenue

Davis, California 956161

USA

wtwoo@ucdavis.edu

fax: 530-752-9382 
October 14, 2001

\title{
Geography, Economic Policy and Regional Development in China
}

\author{
Sylvie Démurger, Jeffrey D. Sachs, Wing Thye Woo, Shuming Bao, \\ Gene Chang and Andrew Mellinger
}

\section{Introduction}

Substantial disparity in regional incomes is a reality in every geographically large country, and the causes of the disparity are numerous and complex. The enduring character of many cases of regional backwardness is also a reality, for example, the Appalachians in the United States, Northern Shaanxi in China, Chiapas in Mexico, and Madura in Indonesia. The persistence of regional poverty has led many prominent social scientists to see the primary causes of entrenched regional poverty to be interrelated in a self-reinforcing manner.

Sociologists talk about the culture of poverty. Psychologists highlight the absence of the drive to achieve. Classical Marxists expound on the systemic tendency of the capitalist economy to generate a reserve army of unemployed. Latin American dependenistas see domestic regional disparity to be the inevitable reflection of the neo-imperialistic relationships in the international arena, the global metropolis-periphery arrangement reproduced within the dependent economy. Finally, neoclassical economists explicate the working of local dynamics that produce multiple equilibria, with the "low-income trap" being one of the stable outcomes.

Natural scientists too have their own discipline-based explanations for spatial inequality in economic development. The most well-known recent example is the book Guns, Germs and Steel by the physiologist Jared Diamond (1997). One of Diamond's main arguments is that many types of innovation (especially those in agriculture and construction) are not transferable across ecological zones. So, in ancient times, while improved varieties of crops and beasts of burden can spread from northern Asia in the East to Europe in the West (and vice versa), they cannot be transmitted from the temperate zone in North America to the temperate zone in South America because of the intervening tropics. Biological endowments also matter. Most areas of Asia and Europe have more naturally pliable livestock (horses and cows) that can be harnessed to help in war and production. The African-equivalent of those animals, e.g., zebras, hippopotamuses, antelopes, and wildebeests, have proved themselves, up to today, resistant to efforts to turn them into beasts of burden. Even the African elephant is temperamentally 
uncooperative compared to its Asian cousin.

There is clearly no shortage of explanations for regional disparity and its sometimes centuries-long durability. This surfeit of views is suggestive of inadequate understanding about this phenomenon, and confusion about what to do about it. What is clear, however, is that the successful development strategies of some countries cannot produce the same salubrious results when implemented in other national settings. When China opened some coastal pockets for foreign direct investment, these Special Economic Zones (SEZs) quickly blossomed into vibrant export platforms and created backward linkages with the immediate hinterland. When landlocked Mongolia turned the entire country into a free trade and investment zone in the late 1990s, however, the inflow of foreign capital was a mere trickle compared to China's experience. The specific lesson in this case is that the time-tested effective growth policy package for a coastal economy, and minor modifications of it, are unlikely to work for an interior economy.

Public concern for regional income disparity in China has been increasing quickly since the early 1990s. This concern is rooted in the widening of provincial income gaps that started in the 1988-93 period, with the exact timing dependent on the method of measurement. Figure 1 shows the coefficients of variation of per capita provincial incomes constructed from two samples.

The first sample consisted of 28 provinces that had complete income data for the 195298 period. 2 The coefficient of variation of GDP per capita (measured in 1995 prices) of the 28 provinces, Cov28, increased significantly from 0.45 to 0.54 over the $1958-60$ phase of the Great Leap Forward campaign to boost output growth through a combined program of large-scale agricultural collectivization and large-scale investments in heavy industries. The flow of investment funds to the existing industrial bases in the Northeast was so massive that real GDP per capita in 1958 jumped 40 percent in Liaoning, 25 percent in Jilin, and 34 percent in Heilongjiang. Unfortunately, the growth strategy of the Great Leap Forward turned out to be disastrously wrong. The resulting economic crash created a nationwide famine that brought the

\footnotetext{
${ }^{1}$ Unless otherwise indicated, the income data are from the National Bureau of Statistics (NBS 1999a). The three main components (primary, secondary, and tertiary sectors) of provincial GDP are recalculated at 1995 prices, and then summed up to obtain the real GDP series of the province, measured in 1995 prices.

${ }^{2}$ GDP data for Tibet and Hainan were available only after 1978. Chongqing data were consolidated with those of Sichuan by updating Sichuan data from the State Statistical Bureau (SSB 1997a) from 1996 onward with data on Chongqing and Sichuan in subsequent years of the China Statistical Yearbook (SSB 1997b, 1998; NBS 1999b).
} 
country to subsistence level, a feat that had the fortuitous result of attenuating the provincial income disparity drastically, as evidenced by Cov28 dropping to 0.38 in 1961 . $^{\text {B A steady }}$ increase in provincial income inequality accompanied the recovery from the depression (196265) and the renewed growth during the decade of the Cultural Revolution (1966-76). Cov28 reached 0.68 in 1978, the eve of the implementation of market-oriented economic reforms. Cov28 reversed course temporarily to decline gradually to 0.62 in 1987-89 before resuming its upward march to reach 0.71 in 1998.

Cov28 may not be a satisfactory indicator of interprovincial inequality, however, because it gives Beijing, Shanghai, and Tianjin (which are metropolises with province-level status) the same weight as the provinces that are much larger in population and land area, and much more diverse in economic characteristics. We hence constructed another coefficient of variation, Cov25, that excluded these three province-level cities. Cov25 shows a much lower degree of inequality than Cov28, and does not show the upward trend seen in Cov28 during the 1966-78 period (table 1). These two differences mean that the three major cities have always been substantially richer than the other provinces, and that the gap between them widened substantially during the period of orthodox socialist economic management. The vast gulf that we see between urban and rural income in today's market economy is definitely not a new phenomenon.

Both Cov25 and Cov28 show that a clear upward trend in provincial income inequality had emerged by 1992, and that the present level of provincial income disparity is unprecedented since the founding of the new China in 1949. Cov25 exceeded the 1961 peak of the Great Leap Forward in 1995, and then went on to reach 0.43 in 1998.

By 1995, the obvious rise in regional inequality had caused the international news media to raise the possibility of the political disintegration of China. ${ }^{7}$ The optimistic scenario for China's breakup is an amicable one. The affluent provinces could now afford to quietly ignore the authority of the central government, or to indirectly control the central government-a situation in either case of de facto political independence for the affluent provinces. The 11 May

\footnotetext{
${ }^{3}$ In 1961, real GDP per capita fell 57 percent in Liaoning, 23 percent in Jilin, and 45 percent in Heilongjiang. Per capita income in these three provinces climbed back to their 1961 levels only in the mid-1970s-a feature that indicates to us a general overstatement of output during the Great Leap Forward period. It is estimated that about 30 million people starved to death during the four years of the Great Leap Forward.
} 
1995 issue of the Far Eastern Economic Review carried on its cover the heading "Fragile China: Affluent Regions Go Their Own Way" and it reported that the political scientist Susan Shirk "knows of a half-dozen provincial functionaries who 'have declined promotions to Beijing and opted to stay at home to get rich and exercise informal political influence.' With regional fortunes so drastically on the rise, Shirk says, national politicians are tempted to play [to] the provinces and outbid each other in pandering to local interests."

The pessimistic scenario for the political disintegration is a civil war sparked by the resentment of the poor provinces. According to the economist $\mathrm{Hu}$ Angang, who advocates the abolition of the SEZs: "If Deng Xiaoping knew the disparities were as big as they are, he would be more militant than I am in trying to eliminate them ... In America, the deep differences between the North and the South more than 100 years ago led to the Civil War," and $_{\text {"We }}$ must cease subsidizing rich coastal cities. Preferential treatment should be reserved for the poor."

The concern for social equity and social stability has led China's top leaders to commit themselves to accelerating the economic growth of the interior provinces. The budgets for infrastructure investments in the poor provinces have increased substantially every year, and a Western Region Development Office has just been established under the State Council (the Chinese cabinet) to formulate a comprehensive development strategy and to coordinate its implementation.

The question of regional inequality in China has been extensively studied in recent years, from both a microeconomic perspective (individual or household income inequality) and a macroeconomic perspective (GDP per capita or consumption level differences between

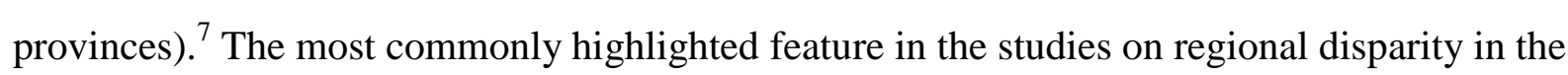

\footnotetext{
${ }^{4}$ This important political backdrop explains why some of the recent outstanding books on China's economic geography are written by, or with, political scientists, e.g., Cheung, Chung, and Lin (1998), Wang and Hu (1999), and Yang (1997).

5 “Deng's Economic Drive Leaves Vast Regions of China Behind," New York Times, 27 December 1995.

6 "China: A Chinese New Deal," Newsweek, 9 October 1995. The South China Morning Post ("Clash over shrinking coffers," 23 September 1995) reported that "Mr. Hu slapped the SEZs in the face by accusing them of ripping off the rest of China - and widening the regional gap - by abusing the special policies granted them by the Centre ... [and he] concluded that the zones "should no longer be allowed to remain special." ",

7 To cite but a few: Lyons (1991), Tsui (1993, 1996), Lee (1994), Chan, Hseuh, and Luk, (1996), Chen and Fleisher (1996), Zhao (1996), Fleisher and Chen (1997), Gundlach (1997), Mody and Wang (1997), Li, Liu, and Rebelo (1998), Raiser (1998), Lin, Cai, and Li (1999), Naughton (1999), Wang and Hu (1999), Wu (1999), Berthélemy and Démurger (2000), Chen and Feng (2000), Dayal-Gulati and Husain (2000), Démurger (2000, 2001), Wei (2000), Aziz and Duenwald (2001), Fujita and Hu (2001), Kanbur and Zhang (2001), Tian (2001), and Zhang, Liu, and Yao
} 
post-1978 period is the growing gap in both the income levels and the income growth rates between the coastal provinces and the inland provinces. A broad range of reasons has been forwarded to explain the divergence of regional income. Possibly the most common explanation is that the coastal provinces have received preferential policies from the central government. While there is no doubt that the preferential policies have promoted the growth of the coastal economies, there is also no doubt that the coastal economies are most advantageously located to engage in international trade, and hence are most able to industrialize by relying on manufactured exports. So, the coastal dummy variable used in many studies is an amalgam of "pure geography effects" and "preferential-policy effects.,

Some studies (Fleisher and Chen 1997, Mody and Wang 1997, and Démurger 2001) have found an indirect route to assess the role of geography in regional growth by focusing on policy measures that are undertaken to overcome geographical obstacles to trade, notably differences such as infrastructure investment in communications, e.g., roads, railway, waterways, and telephones. These studies found that infrastructure investment has a statistically significant positive impact on growth.

This paper tries to provide further evidence for the distinct roles of geography and policy by integrating some recent advances in regional science, ecology, and geography into economics to arrive at some preliminary findings on the barriers to economic growth in China's interior provinces. In particular, we use an original dataset that allows us to account directly for geography (i.e., access to the sea and elevation/slope), and we propose alternative measures for preferential treatment given to some provinces. We then present estimates on the respective contributions of preferential economic policies and geographical location to the growth of China's provinces. The quantification and policy suggestions presented here are necessarily tentative and primitive, because this is the first phase of a collective effort to understand this longstanding problem of large regional inequality in China's history.

Before detailing our analysis of regional disparity and our decomposition of the coastal dummy into "pure geography effects" and "preferential-policy effects," it is important to

(2001). Besides the English-written literature, there is also an important Chinese-written literature that is not cited here.

${ }^{8}$ One exception lies in Wang and $\mathrm{Hu}(1999$, ch. 4), who provide some useful insights of the role China's heterogeneous geographical conditions can play in explaining regional economic disparities. 
understand what preferential policies really mean in the context of China. The so-called "preferential policies" extended to the coastal regions are in essence policies to marketize and internationalize these coastal economies. These preferential policies should rightly be called "deregulation policies" because they allow these coastal provinces to operate in an economic environment closer to those of their East Asian neighbors (and competitors). Firms in these open economic zones could import intermediate inputs duty-free to produce exports; collaborate with foreign companies in investment, manufacturing and distribution; hire and fire workers in accordance with their performance and demand conditions; and escape the confiscatory taxation that is needed in a centrally planned economy to finance its vast, complicated system of social subsidies. In return for these economic liberties, these firms would not receive state subsidies when they experience losses.

The adjective "preferential" gives the misleading sense that the prosperity of these coastal economies had been sustained by a steady flow of state subsidies either from the state budget or from the state bank system. This has not been the case. There was certainly pump priming in the beginning (i.e. fiscal transfers and bank loans to build the infrastructure that would make these open economic zones attractive to the transnational companies as export platforms), but there were no significant steady transfers to prop up failing enterprises in order to maintain the living standard in the region, as in the case of the northeastern provinces. Only the latter could truly be called preferential policies. In short, because a centrally planned economy is an overregulated economy, what the preferential policies really did was to remove some of these regulations, namely, the regulations against the marketization and internationalization of economic activities.

\section{Assessing the importance of geography}

On a global scale, the wealth of nations is well characterized by two geographical divides. The first geographical divide emphasizes differences in ecological conditions: the temperate zone versus the tropical zone. The second geographical divide emphasizes differences in the ability to conduct international trade: the coast versus the interior. As we will show, both of these geographical divides are a combination of independent causes of economic wealth and

\footnotetext{
${ }^{9}$ Lin (2001) studied the role of geography in wage disparity, and found that the geography variables of market access and supplier access explained about 15 percent of the gap between the wage rate of the provinces and the
} 
of proxies for some important determinants of economic prosperity.

The empirical validity of the temperate-tropical divide is well supported by the fact that over 90 percent of the world's poor lives between the tropic of Cancer and the tropic of Capricorn. The result is a GDP per capita (PPP-adjusted) of \$3,326 in 1995 for tropical economies, and $\$ 9,027$ for nontropical economies. This strong correlation between ecological zone and income level is not a new observation in economics, e.g. Lee (1957) and Kamarck (1976), but it has not been a major analytical organizing principle in development economics. The incorporation of new insights from physical geography and societal dynamics have led Diamond (1997), Landes (1998), Engerman and Sokoloff (1997), and Gallup, Sachs, and Mellinger (1999) to focus on physical geography as an overarching explanation of economic performance.

Bloom and Sachs (1998) have identified the virulence of diseases and the limited potential for large gains in agricultural productivity in the tropics to be the key obstacles to economic development in most areas of Africa. This biology-based analysis is of course not the only recent attempt to explain the upward income gradient that begins at the equator. Hall and Jones (1999) have suggested that the distance from the equator proxies for the relative penetration of European economic institutions, and European-style economic institutions are the ultimate engines of growth.

The coast-interior dichotomy highlights the importance of transportation costs in determining a country's participation in the international division of labor. In the industrial age, water transportation has the lowest cost for moving goods over extended distance. ${ }^{10}$ The growth effects of trade are well known, beginning with Adam Smith's observation that productivity improvements are enabled by the greater division of labor that, in turn, is enabled by the expansion of the market. The clear policy lesson here is that investments in physical infrastructure and transportation technology can change the comparative advantage of a region.

The temperate-tropical dichotomy will not be a major analytical organizational principle in this paper. This is because China, unlike Brazil and Australia, does not have a substantial part of its territory within the tropical zone. The southern border of China extends only a few miles

\footnotetext{
average national wage rate.

${ }^{10}$ For example, the industrialization of central Europe was helped by the navigability of the Danube.

${ }^{11}$ For example, the connecting of the Great Lakes to the Atlantic by the Saint Lawrence Seaway accelerated the industrialization of the northern part of the American Midwest.
} 
beyond the tropic of Cancer. This feature is of interest in itself because it is more than coincidental that after centuries of steady southward expansion, the Chinese empire stopped at approximately where the tropical zone begins. While we will not dwell on the temperatetropical divide, the general point about differences in the development potential of different ecological zones is an important one. The appropriate development package for the arid plateaus of northwestern China has to be different from the grain-growing plains of central China, and the relevant development package for the wet, warm southwestern provinces has to take disease vectors into greater account.

\section{China in time and space}

China covers 9.6 million square kilometers and stretches from the temperate to subtropical zones. It is similar in size and climate to the United States but its topography is quite different. The most important difference is that the United States has coastlines running the length of its eastern and western borders, whereas western China is landlocked. China is also more mountainous and hilly, with plains at less than 500-meter elevation making up only 25 percent of the total land area, and mountains and plateaus accounting for 60 percent. These topographic features of China imply higher transportation costs and a greater requirement for physical infrastructure construction. The task of economic development in China is hence more challenging than in the United States.

Physically, China resembles a three-step staircase running downward from west to east. It begins with the 4,000-meter-high Qinghai-Tibet Plateau in the west, proceeds to the highlands and basins in the center that are about 1,000 to 2,000 meters above sea level, and ends with hilly regions and plains that are less than 1,000 meters high. The combination of higher precipitation, a warmer climate, and access to navigable rivers and the sea have made the central and eastern provinces more conducive for farming and trade; hence these areas became the population centers of China. The Qinghai-Tibet Plateau was traditionally the poorest region.

The location of China's economic center has changed over time, moving eastwards from the Loess Plateau and the Yellow River Valley in the northwest (where Chinese civilization began in $2000 \mathrm{BC}$ ), which is about 1,000 kilometers away from the coast. The reason for this original location is that, in ancient times, high agricultural productivity and land-based trade was much more important than sea-based trade. The bulk of China's international trade at that time 
was conducted through the famous Silk Route that went through the northwestern corner of China. The southeastern coastal region, where Guangdong and Fujian (two of today's most dynamic provincial economies) are located, largely remained uncultivated and sparsely populated in early Chinese history. Although the natural conditions in the southeast were favorable for agriculture, farming was undeveloped because malaria and other subtropical diseases checked population growth, and the high temperatures sapped human energy faster, resulting in lower labor productivity. Guangdong was considered an almost uninhabitable place in ancient times.

Over time, the pressure of expanding population and the frequent invasions by the northern tribes caused more of the population to move south and into the mid-coastal and southeastern regions. By the twelfth century, the Yangtze River valley had become very developed and densely populated. The economic importance of the coastal region increased dramatically after the Opium War in 1840, when the Western powers forced China to first open several ports and then the whole country for trade. China's economy and subsequently its politics were quickly (by historical standards) transformed. International trade expanded, foreign direct investments flowed in, and local industrialists made their appearance, especially in the mid-coastal and southeast regions. The Qing dynasty was overthrown in 1911, followed by a long chaotic period of protracted civil wars and Japanese colonialism, which ended with the foundation of the People's Republic of China on 1 October 1949 by the Communist Party of China (CPC) under the leadership of Mao Zedong.

Table 2 summarizes some key geographical and economic characteristics of China in the following six regional groupings that are useful for analyzing the post-1978 period. 13

1. The metropolises of Beijing, Tianjin, and Shanghai have province-level status. (Chongqing was granted province-level status in 1997, but we have included its data under Sichuan province.) These are the richest pockets of China and have had high growth in the 1990s. These cities are highly industrialized, and over 71 percent of their population lives within 100 kilometers of the coast or navigable waters. Beijing,

\footnotetext{
${ }^{12}$ The great Chinese poet of the eleventh century, Su Dongpo (1037-1101), who was banished by the emperor to Guangdong, wrote that the only saving grace of living there was the abundance of the lichee fruit: "Having three hundred lichees daily, I do not mind to be a person living in the south of Nanling Mountain [where Guangdong is located]."
} 
Shanghai, and Tianjin are the exceptionally rich (city) provinces.

2. The northeastern provinces of Heilongjiang, Jilin, and Liaoning, which are collectively called Manchuria, were the industrial heartland of China in 1949 (because of the Japanese control of the economy that started in 1905). ${ }^{14}$ During the central planning period, their early start in industrialization was consolidated, making these provinces the part of China that most resembled the Soviet Union in industrial organization and production structure. In the national ranking of GDP per capita (after omitting the three metropolises) Heilongjiang and Liaoning ranked first and second, respectively, in 1978 and ranked seventh and fifth, respectively, in 1998. Heilongjiang and Liaoning are the traditionally rich provinces.

3. The coastal provinces are Hebei, Shandong, Jiangsu, Zhejiang, Fujian, Guangdong, and Hainan (Hainan was separated out from Guangdong in 1988). These seven provinces have 82 percent of their population living within 100 kilometers of the sea or navigable rivers. They have grown the fastest of these six groupings in the 1978-98 period, at an annual average of 10.7 percent. The result is that Zhejiang and Guangdong have soared to the top of the GDP per capita ranking (omitting the metropolises), from fourth and sixth, respectively, in 1978 to first and second, respectively, in 1998. Zhejiang and Guangdong are the archetype of the nouveau riche provinces.

4. The central provinces are Shanxi, Henan, Anhui, Hubei, Hunan, and Jiangxi, through which the plain runs relatively unimpeded from the north of the Yellow River to the south of the Yangtze River. The temperature and rainfall make this region the agricultural heartland of China, which explains why its population density is almost twice that of the northeastern and southwestern regions. The two large rivers and their many tributaries endow 57 percent of the population with easy water transportation. The Yangtze Valley between Wuhan and Shanghai has the industrial potential of the Rhone Valley, possibly, multiplied several times.

5. The northwestern provinces of Inner Mongolia, Shaanxi, Ningxia, Gansu, Qinghai,

\footnotetext{
${ }^{13}$ The geographical delineation of China has varied from one study to another. As the same term (e.g., "coastal") can refer to different subsets of provinces, we shall try to indicate to the reader whenever the regional term changes meaning in our discussion of the literature.

${ }^{14}$ The Japanese started their economic penetration into Manchuria in 1895, after defeating China over the control of Korea. They began their economic domination from 1905 by taking over Russian economic interests; rendered Manchuria a puppet state after 1911; and formally annexed Manchuria in 1935.
} 
Xinjiang, and Tibet (data of Tibet omitted) are truly isolated. The center of the land mass is 1,400 kilometers from the coast. This region is more arid and steeper compared to the four previous groupings, and it is marked by desert on its western and northern borders. Furthermore, 5 percent of the land has a slope of greater than 10 percent compared to 2.5 percent for the northeastern, coastal, and central provinces. The general lack of water makes the region difficult for agriculture, and only 8 percent of the land is arable, which helps explain why it has the lowest population density in China in 1998: 46 persons per $\mathrm{km}^{2}$ versus 126 persons per $\mathrm{km}^{2}$ in the southwestern region, which has the next-lowest population density. A large number of residents are of Turkic origin and are practicing Muslims. ${ }^{15}$ The Han people are in the minority in Xinjiang and Tibet.

6. The southwestern provinces of Sichuan, Yunnan, Guizhou, and Guangxi have rainfall and temperature conditions that are ideal for crop cultivation, but they suffer from being too mountainous. The average elevation is 1,428 kilometers, the average slope is 5.2 degrees, and 14 percent of the land has a slope of greater than 10 degrees. The proportion of arable land of 10 percent is barely above that of the arid northwestern provinces. Lacking the mineral resources of the northwestern provinces, the southwestern provinces have the lowest GDP per capita in 1978, and the lowest growth rates in the period of market-oriented reform. A significant proportion of the population belongs to non-Han ethnic groups.

\footnotetext{
${ }^{15}$ In the 1950s, 3.5 million of Xinjiang's population of 5 million were Muslims Uighurs, with Han Chinese accounting for less than 200,000. It is estimated that 6 million Han Chinese have settled there since then, bringing the total population to about 16 million in 1994, with 62 percent belonging to non-Han ethnic groups. Data are from "Wang Enmao, 87, Who Ruled a Rebellious Chinese Province," The New York Times, 23 April 2001, and "Xinjiang's Minorities Feel Torn Between Desire for Independence, Benefit of Economic Reform," The Asian Wall Street Journal Weekly, 5 September 1994.
} 


\section{Regional economic policies in China}

The central planning period, 1949-78

Industrialization was shallow in 1949 and largely a coastal phenomenon. ${ }^{16}$ In 1952, the secondary sector produced 8 percent of GDP and employed 7 percent of the labor force compared with the primary sector, which produced 74 percent of GDP and employed 84 percent of the workforce. The coastal provinces had 72 percent of fixed assets and accounted for 69 percent of the gross value of industrial output. ${ }^{17}$ Naturally, just like the Communist Party of the Soviet Union in 1917, the CPC in 1949 saw its most important economic task to be industrialization.

China adopted the two key sets of guiding principles behind the Soviet development strategy: (a) the Marxist principles of common ownership with the state as trustee, and of generalized egalitarianism; and (b) the Stalinist practices of central planning for resource allocation, suppression of light industries and services in favor of heavy industries, and minimization of trade and financial linkages with the capitalist economies.

Mao added a third guiding principle to China's economic policymaking, the principle of regional economic self-sufficiency: a region should be self-sufficient not only in food production but in industrial goods as well. This third principle unquestionably had the greatest impact on regional economic outcomes. The self-reliance principle had several virtues. The first was that it overlapped with the egalitarian principle because it reduced provincial inequality, which Mao had identified to be one of the key social contradictions to be eliminated in the new China. 18. second virtue was that the biggest beneficiaries of the self-reliance principle were the poorest provinces (because they were overwhelmingly agricultural), and this distributional outcome was in accordance with the gratitude that many veteran party leaders felt toward these provinces. Many of the poorest provinces provided a haven for the CPC to rebuilt its strength after the

\footnotetext{
${ }^{16}$ In this section we use the classification of coastal, central, and western provinces, which is the one commonly used in official publications. The coastal provinces are Beijing, Tianjin, Hebei, Liaoning, Shanghai, Zhejiang, Fujian, Guangxi, Jiangsu, Guangdong, Hainan, and Shandong. The central and western provinces are collectively called interior provinces. Wang and $\mathrm{Hu}$ (1999) used two schemes: (a) metropolitan cities, eastern provinces, central provinces, and western provinces (Table 3.1); and (b) coast, central, and west (Table 6.1). Wang and Hu's definition of coast corresponds to the official classification, and it equals, in their first classification, metropolitan cities plus eastern provinces plus Guangxi.

${ }^{17}$ The data are from Yang (1997, table 2.2).

${ }^{18}$ Mao (1956).
} 
Kuomintang had driven it out of the urban areas. 19

The third, and most decisive, virtue of self-sufficiency was that, beginning in 1963, it coincided with the national security considerations of China. The worsening Sino-Soviet political relationship and the growing military presence of the United States in Vietnam convinced Mao that regional economic self-sufficiency was key to China being able to engage in a protracted defense of its territory. Mao and his generals envisaged three lines of defense (coastal, central, and western), and they decided in 1964 on a massive construction of militaryindustrial complexes in western China, the third line of defense, popularly translated as the "Third Front." To minimize the vulnerability of the third-front industries to air attacks, Lin Biao, then the Defense Minister and Mao's designated successor, instructed that these projects be located "in mountains, in dispersion, and in caves."

The first two virtues of the self-sufficiency principle helped to ensure that the First FiveYear Plan (1953-57) allocated 56 percent of state investment to the interior provinces, and that the Second Five-Year Plan (1958-62) allocated 59 percent. As the concern for national security grew in the early 1960s, the Third Five-Year Plan (1966-70) allocated 71 percent of state investment in the interior provinces, with the bulk of it in Sichuan, Hubei, Gansu, Shaanxi, Henan, and Guizhou. Furthermore, many companies in Shanghai and other coastal cities were relocated to the mountains in Guizhou, Sichuan, and Hubei, where highways and railroads were deficient or nonexistent, water and electricity were in short supply, and the sources of raw materials were far away. A significant proportion of the relocated factories could not produce anything for many years, and the equipment rusted into junk.

Post-mortem studies of the third-front industries concluded that "only half of the factories built performed to design specifications and the rest were either only partially completed (30 percent) or not completed at all (20 percent). Fully one-third of the total investment was wasted .... . 21 One such example of wastage was the Second Automobile Company, built in the mountains of Hubei. The parts and assembly plants were scattered over the mountainous region, transportation between the plants was poor, and they were far away from their input suppliers

\footnotetext{
${ }^{19}$ According to Lane (1998): "Yan'an [in Shaanxi] became the cradle of the Chinese revolution and earned a lasting place in the hearts of party members who lived there. ... The First Five-Year Plan (1953-57) targeted the province as a key site for industrial development, and 24 of the plan's 156 major projects undertaken with Soviet assistance were located there."

${ }^{20}$ Quoted in Yang $(1997,19)$.

${ }^{21}$ Yang $(1997,19)$.
} 
and the final consumers of their products.

Given the large amount of wastage that occurred in the industrialization of the interior provinces, it is no wonder that even though the interior's share of fixed assets went from 28 percent in 1952 to 57 percent in 1983, its share of the gross value of industrial products only went up from 31 percent to 41 percent. The primary causes of the higher productivity of the coastal industries were that the coastal provinces had deeper pools of management and technical expertise, better linkages between the industrial enterprises and the local economies, and a more developed infrastructure. It has been estimated that 100 yuan of fixed asset investment in 1978 yielded 70 yuan of output from the third-front enterprises, compared to 141 yuan from the coastal enterprises. The profit rate in 1978 was 9 percent for the third-front enterprises, compared to 23 percent for coastal enterprises. 22

The pouring of investment funds into the interior provinces was a clear violation of the comparative advantage principle. The growth of the interior provinces not only occurred at the expense of the coastal provinces, it also lowered the overall growth rate of the economy. The discrimination against the coastal region was so severe that although Shanghai provided more than 40 percent of the state revenue during the Cultural Revolution period, it was not even allowed to retain enough funds to cover the depreciation of its capital stock.

From 1972 to 1978 , China reduced its discrimination against investments in the coastal provinces and increased its economic interaction with the capitalist economies. This policy shift occurred because the government realized that China's economy and technological capacity was falling further behind the rest of the world. If this negative trend was not reversed, China might not be able to defend itself. Furthermore, because the Soviet Union was fast becoming a bigger threat than the United States, an invasion through the traditional land route by the Soviet Union had become much more likely than a coastal landing by armed forces supported by the United States. The national security justification for the third-front industries was hence undermined. Economic modernization required the import of foreign technology, and this necessitated that China increase its export earnings.

With the improvement of Sino-U.S. relations on course after Kissinger's secret visit in July 1971, the coastal enterprises, especially those in Guangdong, were expanded in order to increase their export capacity. Total export earnings jumped from US\$2.6 billion in 1972 to

\footnotetext{
${ }^{22}$ Data from Yang (1997).
} 
US\$3.4 billion in 1973, and continued soaring to reach US\$9.8 billion in 1978. Just as national security considerations in the 1950s and 1960s had played a large part in justifying the bias in favor of investments in the interior provinces, national security considerations in the face of changes in international politics in the 1970s helped to reduce this bias.

\section{The market-oriented reforms period, 1978-98 23}

The process of increased economic interaction with the outside world accelerated at the end of 1978 upon the decisive political victory by the rehabilitated cadres over the remnants of the Maoist establishment at the Third Plenum of the Eleventh Party Congress. The strategy on the domestic front was the decentralization of agricultural production, the decentralization of the fiscal system, and the deregulation of prices; the strategy on the international front was the Open Door Policy.

Fiscal decentralization took the form of tax contracting between the central government and the provinces. ${ }^{24}$ Each fiscal contract was individually negotiated, and it ranged from fixed lump-sum contracts for five years, such as in the cases of Guangdong and Fujian, to highly complicated (province-specific) revenue-sharing formulae. The provincial governments in turn negotiated individual revenue contracts with the local governments. Since the marginal tax rate set by the central government varied tremendously across provinces, the incentive of the provincial and local governments to engage in local economic development in order to generate tax revenue also varied tremendously. Given the importance of Shanghai to the central coffers, its marginal tax rate was set higher than that of most coastal provinces until the early 1990s.

The fiscal decentralization might have helped economic growth, 25 but it led to state revenue declining from 35 percent of GDP in 1978 to 14 percent in 1992, producing a near fiscal crisis for the state. The state lacked the funds to invest in infrastructure projects to remove production bottlenecks and to undertake poverty alleviation programs. The practice of each provincial government covering more of its expenditure from local revenue necessarily meant

\footnotetext{
${ }^{23}$ There is a keen controversy about what are the fundamental economic mechanisms in the rapid growth of China after 1978. Some economists (the experimentalist school) believe that the growth was enabled by the discovery of new nonstandard economic mechanisms, e.g. collectively owned rural enterprises and fiscal contracting, while others (the convergence school) see the growth as the result of moving toward a private market economy, whereby best international practices are adopted and modified according to local conditions. See Sachs and Woo (2000) and Woo (2001) for a review of this debate.

${ }^{24}$ For details, see Wong, Heady, and Woo (1995).
} 
reduced development expenditure in the poorest provinces that had been receiving fiscal subsidies from the center. The tax reform of 1994 that had the value-added tax as its centerpiece has reduced the discriminatory elements of the fiscal system, but it has not restored the fiscal capacity of the state to help the poorer provinces significantly.

The deregulation of prices in the industrial sector initially took the form of a dual track price system for industrial inputs. Since the central and western provinces were the main suppliers of raw industrial materials, the continuation of artificially low prices for these industrial inputs meant that the dual track pricing system was in effect transferring income from the interior producers to the coastal factories. The elimination of the dual track price system in the 1990-91 period was an equitable move from the viewpoint of regional disparity.

The Open Door Policy consisted of attracting foreign direct investment and promoting foreign trade in targeted areas. This opening up was initially limited to two southern provinces (Guangdong and Fujian), then gradually was extended to larger geographical units: first along the coast and then to the inland provinces. The open economic zones provided investors with various preferential tax treatments, and exemptions on duties and from labor regulations. ${ }^{27}$ The implementation of regional preferential policies has gone through the following three broad stages:

1. Early 1980s: opening to a limited extent, in Guangdong and Fujian provinces, with the establishment of SEZs in 1979-80.

2. Middle to end of the 1980s: coastal preference strategy enforcement, with the designation of Coastal Open Cities (COCs), which were entitled to set up their own Economic and Technological Development Zones (ETDZs), in 1984; followed by the establishment of Coastal Open Economic Zones (COEZs) in 1985; an Open Coastal Belt (OCB) in 1988; and the Shanghai Pudong New Area in 1990.

3. Early 1990s: further extension of Open Door Policy to all of China, after Deng Xiaoping's southern inspection trip (nanxun) in 1992. During this year, new open economic zones were officially started in Major Cities along the Yangtze River (MC), Border Economic Cooperation Zones (BECZs), Capital Cities of inland provinces and

\footnotetext{
${ }^{25}$ The evidence on this front is mixed; e.g., Chen (forthcoming) and Zhang and Zou (1998) found negative relationships between fiscal decentralization and economic growth. See the review in Woo (2001).

${ }^{26}$ See Ahmad, Li, and Richardson (2000) for a recent discussion of China's tax system.
} 
autonomous regions (CC), ETDZ, and Bonded Areas (BA).

Table 3 gives additional details of the establishment of these various types of economic zones up to 1994. The acceleration in the opening-up process in 1992 led to an inflated number of so-called open economic zones, set up by local officials without proper authorization. Besides the official policy launched by the State Council, the 30 provinces, as well as hundreds of counties and townships, started to formulate their own preferential policies for foreign investment in specific "development zones." As a consequence of this "zone fever" (Yang 1997, 53), there were around 2,000 open economic zones of various kinds at and above the county level by 1993 (and probably even more below the county level), offering tax exemptions and reductions of all sorts in order to attract investment. Following the implementation of the austerity program in 1993, most of these unapproved zones have been closed, 28 and regional policies have tended to equalize over time (at least up to 2000).

The leading role of this selective open-door policy in regional growth has been emphasized by a great number of studies (e.g. Lee 1994, Mody and Wang 1997, Berthélemy and Démurger 2000, Chen and Feng 2000, and Démurger 2000). Most of them found that foreign direct investment (FDI) had an impact on economic growth that went beyond an addition to the capital stock: it also provided competition to domestic firms and hence forced them to raise their productivity, generated demonstration effects that enabled domestic firms to improve their operations, and provided a training ground for future managers of domestic firms in the same industries. Démurger (2000) concluded that FDI was a very effective channel for technology transfer that mainly benefited the coastal provinces, because most of the FDI was concentrated there.

FDI inflows did not occur immediately in large volumes in response to the establishment of the SEZs in southern China (1979 in Guangdong and 1980 in Fujian), partly out of caution and partly because the liberal regulatory framework began to be introduced only in 1982. 29 FDI started pouring in only from 1984 onward (when it doubled from US\$0.6 billion in 1983 to US\$1.3 billion in 1984). This jump in total FDI in 1984 was not simply due to the opening of 14

\footnotetext{
${ }^{27}$ Details on the different preferential policies applied in these zones can be found in Yang (1997, ch. 3), Ma (1999, ch. 7), Wang and Hu (1999, ch. 6), Chen (2000), and Démurger (2000).

${ }^{28}$ For example, the central government closed 1,000 of the 1,200 economic development zones that it had not authorized in the coastal provinces of Liaoning, Hebei, Shandong, Jiangsu, Zhejiang, Fuijian, Guangdong, and Guangxi; see "State closes 1,000 EDZs to better efficiency," China Daily, 13 August 1993.
} 
COCs and 10 ETDZs that year, because there was an enormous rise in FDI into the existing SEZs as well. FDI into Guangdong increased from US\$245 million in 1983 to US\$542 million in 1984, and FDI into Fujian increased from US\$14 million to US\$48 million in the same period. This acceleration in FDI in 1984 was most probably the result of foreign investors being finally convinced, by the opening of the 24 additional FDI zones, that China was committed to integration into the world economy.

The second large acceleration of FDI inflow occurred in 1992, when FDI went from US\$4.4 billion in 1991 to US\$11.0 billion in 1992. This further increase in the confidence of foreign investors was doubtlessly brought about by Deng Xiaoping's call for increased economic openness and his warning that China faced greater threats from leftist thinking than from rightist thinking, during his nanxun in early 1992. 30

\section{Regional development in China, 1952-98}

\section{Provincial growth experiences}

The distribution of per capita GDP growth rates is given in tables 4 and 5. Several subperiods can been distinguished according to growth acceleration or deceleration. This leads to the following policy episodes:

- 1953-58: the orthodox centrally planned economy

- 1959-65: the Great Leap Forward, the economic collapse, and recovery

- 1966-78: the Cultural Revolution

- 1979-84: first reform phase, emphasis on agriculture

- 1985-91: second reform phase, Oskar Lange-inspired reforms

- 1992-98: third reform phase, the ultimate goal of which is a market economy with substantial diversification of ownership structure

Figure 2 shows that there is no evidence of any unconditional $\beta$-convergence across Chinese provinces during the planned and reform periods. This is confirmed by cross-section regressions on the whole period and by subperiods (not reported here), which all indicate that there is no significant relationship between the per capita GDP annual growth rate and its initial

\footnotetext{
${ }^{29}$ Jiang Zemin played a prominent role in getting the liberal regulatory framework for SEZs passed in November 1981; see Gilley $(1998,68)$.

${ }^{30}$ See Lemoine (2000) for an excellent analysis of FDI, and its role in international trade in China.
} 
level, except for the last subperiod (1992-98), during which a $\beta$-divergence phenomenon emerged.

\section{Provincial income disparity, 1952-98}

Table 6 shows the ranking of China's provinces by GDP per capita (1995 prices) in key years of China's economic history. The data indicate the following:

1. The provinces that moved up most in the income ranking during the planned period were Beijing, Qinghai, and Ningxia, and the provinces that moved down most during the reform period were Qinghai and Ningxia. The rise of Beijing's relative standing, and the maintenance of its attained income rank, reflected its paramount political status in the country. The initial large gains of Qinghai and Ningxia (up 10 and 8 places, respectively), and the subsequent large reversals (15 and 10, respectively) showed the tremendous transfer of resources to interior provinces during the planned period.

2. There has been basically no change at the very top and the very bottom of the scale. The three metropolises were in the top tier throughout the whole period, and Yunnan, Shaanxi, Gansu, and Guizhou remained the poorest provinces. Mobility, both upward and downward, was a middle-class phenomenon.

3. The provinces that improved their ranking most significantly during the reform period were the coastal provinces, especially Fujian, Shandong, and Hainan. The traditional industrial bases of northern China (Heilongjiang, Jilin, and Liaoning) and the western provinces experienced a decline in their income rankings.

Table 7 examines income inequality further by focusing on the changes in the gap between the five richest provinces and the five poorest provinces. The absolute income gap increased tremendously in both the planned and reform periods. The relative income gap, defined as the absolute gap normalized by the average national income, increased from 1.0 in 1952 to 1.5 in 1978 and then dropped slightly to 1.4 in 1998 . The ratio of the incomes of the two groups rose from 2.6 in 1952 to 3.4 in 1978 and then to 3.6 in 1998. The relative income gap and the income ratio essentially agree that the disparity between the richest and the poorest provinces did not change during the reform period. In any case, the changes in the relative

\footnotetext{
${ }^{31}$ The corresponding cross-section regression is $\mathrm{g}_{92-98}=-0.022[0.059]+0.016[0.007] * \operatorname{Ln}\left(\right.$ p.c.GDP $\left.{ }_{91}\right)$. The values shown between brackets are robust standard errors. The number of observations is 29 , and the R-squared is 0.1 .
} 
income gap and in the income ratio in the reform period are small compared with the changes in the planned period, where the respective increases in 1952-78 were 52 percent and 31 percent. The relative movements during 1952-78 and 1978-98 confirm the conclusions of urban bias and industry bias drawn from the movements of the coefficient of variation for all provinces, Cov28.

\section{Geography and differences in per capita income}

In this section, we provide a preliminary impression of how much of the difference in per capita GDP levels across provinces could be accounted for by geography. Our knowledge of changes in China's economic structure and policy regime in the 1952-98 period suggests at least two channels through which geography has influenced provincial income levels. The first channel is agriculture, and the second channel is international trade and FDI.

China was a predominantly agricultural economy until the middle of the 1980s. The proportion of the national labor force employed in agriculture was 71 percent in 1978, 59 percent in 1988, and 50 percent in 1998. There were big differences in the degree of structural transformation across provinces, but agriculture remains the dominant economic sector for most noncoastal provinces. To illustrate the continued importance of agriculture, table 8 reports the agricultural share of employment and output in selected western, central, and coastal provinces for 1978, 1988, and 1998. In 1978, the agricultural share of employment in 1978 was over 70 percent in the northwestern, southwestern, central, and coastal provinces, and about 50 percent in the northeastern provinces. The 1998 agricultural shares of labor in the northwestern, southwestern, and central provinces were all over 58 percent, still significantly higher than the 1978 agricultural share of labor in the northeastern provinces. The agricultural share of GDP in 1988 was over 25 percent for the northwestern, southwestern, central, and coastal provinces; it was over 35 percent for the central and southwestern provinces. Given the large size of the agricultural sector in many provinces during 1978-98, agricultural productivity was an important determinant of provincial income per capita. Since differences in provincial topographical features, such as elevation and flatness of arable land, help shape differences in agricultural productivity across provinces, they should also help to explain differences in provincial income.

Geography also affects provincial income through physical location. The low cost of water transportation makes the coastal provinces and areas along navigable rivers that flow to the sea better suited to be platforms for producing manufactured exports. When allowed by the 
government, domestic firms located in these regions would naturally expand production to service foreign markets, and foreign firms would relocate their production there, given the low cost of Chinese labor. Hence, provinces with easy access to sea transportation received boosts to their incomes from international trade whenever China did not cut itself off from the international economy.

We use three benchmark years - 1952, 1978, and 1998-for our econometric exploration of the role of geography in provincial income determination. The 1952 distribution of provincial GDP per capita is regarded as the outcome, primarily, of market forces because of the newness of the communist regime, and, secondarily, of the various dislocations from the recent wars. The 1978 distribution of provincial income levels is taken to reflect primarily the biases of the central planning system, and secondarily the efforts since 1972 to increase exports (in order to pay for technology imports). The 1998 distribution is seen as the joint result of the marketization and internationalization of the economy since 1979.

The impact of geography on income per capita in 1952, 1978, and 1998 is tested using the following explanatory variables.

1. The ability to participate in sea-based international trade

- Distance from the coast $[$ Distf $=1 /(1+$ distance in $\mathrm{km})]$

- Percentage of population being able to engage in international trade easily: (a) the proportion of the population distribution of a province in 1994 within $100 \mathrm{~km}$ of the coastline or ocean-navigable river, excluding the coastline above the winter extent of sea ice and the rivers that flow to this coastline [Popl00cr]; and (b) the proportion of the population distribution of a province in 1994 within $100 \mathrm{~km}$ of the coastline, excluding the coastline above the winter extent of sea ice $[$ Pop $100 \mathrm{~km}]$.

\section{Topography}

- Percentage of area within a province with a slope greater than 10 percent [Slope10]

- Average slope of a province [Slavge]

- Average elevation [Elavge]

We regressed various combinations of the above explanatory variables using two

\footnotetext{
${ }^{32}$ The assumption is that the distribution of population across China has not markedly changed from 1952 to 1998 , thus allowing us to consider the 1994 figure as an indicator for population distribution throughout the pre-reform period. This assumption is likely to be valid because the household registration system was designed to keep people in the places where they were born.
} 
different data sets: one included all provinces, except Tibet; the other also excluded Beijing, Shanghai, and Tianjin because they are potential "outliers" (because of their small size, specialized economic structure, administrative role, etc.). Table 9 summarizes the results obtained from the different regressions.

Three robust results deserve particular attention because of their interesting implications. First, the three proxies for easy coastal access improved greatly in statistical significance in 1998. Pop100cr was not significant in any of the myriad of specifications for 1952 and 1978 , and "distance from the coast" jumped from a 10 percent significance level in 1952 and 1978 to a less than 1 percent significance level in 1998. This turn to extremely strong statistical significance for the three proxies suggests that the ability of a province to engage in international trade and to host FDI is now a very important determinant of provincial income because of the post-1978 reform policies.

The second interesting robust result is that the "flatness" of land within a province was an important factor in provincial income determination in all three years. An average slope of over 10 degrees always lowered provincial income, and the constantly high statistical significance seen in this relationship could have been generated by geography coming through both the agriculture channel and the trade channel. A steep landscape raises the costs for cultivating crops and transporting goods (and this cost relationship could well be a nonlinear one). Infrastructure construction such as terracing and tunneling can sometimes solve the problem of a hilly terrain, but it is always an expensive solution-even when the solution is an imperfect one.

The third interesting robust result is that the $R^{2}$ is highest in 1998 and lowest in 1978. For example, for the smaller data set, the specification with Pop100km and Slope10 reports an $R^{2}$ value of 0.54 for $1998,0.16$ for 1978 , and 0.20 for 1952 . The fact that the regression specifications fits the data better in 1998 than in 1978 is not surprising, because China had pursued autarkic policies in the two decades prior to 1978, hence weakening the trade channel through which geography asserts itself. The finding that the statistical fit in 1998 was much higher than in 1952 is somewhat surprising, because only a limited part of the communist economic strategy had been enforced by 1952 and it was unlikely to have greatly modified the provincial distribution of pre-1949 market-determined incomes. This difference in fit of the income regressions for 1952 and 1998 suggest many possible explanations, but two of them are most relevant to our geography focus. First, the world today is more integrated economically 
than in 1952, so the gains from economic internationalization may be greater now than in 1952. Second, a favorable geography could have a positive, but slow and cumulative, impact on income, hence yielding a substantial lag between geographical advantage and higher income level. Both of these explanations would predict that the coefficients and statistical significance of the geography variables in a growth regression would be larger in the later subperiods of the estimation period. This prediction is borne out in the growth regressions reported in the next section.

\section{Provincial differences in growth rates (1978-98): Geography and policy}

As mentioned at the beginning, an increasingly widespread concern since 1992 is the growing divergence between coastal and noncoastal provinces, in both per capita GDP growth rates and levels. Among the explanations given for the regional divergence are the following:

1. Preferential policies: the implementation of preferential policies in coastal provinces as early as the beginning of the 1980s led to a rapid integration into the world markets, huge inflows of FDI, and the development of modern industrial sectors in these provinces.

2. Geographic reasons: coastal provinces benefit from a higher percentage of arable land, better conditions to develop infrastructure, and an easy access to the sea. A coastal location is certainly more convenient for export-oriented processing industries, which have been developing very rapidly during the last 20 years.

Up to now, the two factors - geography and preferential policy-have been mainly accounted for through a coastal dummy. To organize the discussion, table 10 reproduces some regression results from the literature on regional growth. As can be seen from Jian, Sachs, and Warner (1996) and Zhang (forthcoming), the coastal dummy does significantly account for differences in economic growth among provinces. ${ }^{3.3}$ As pointed out by Jian, Sachs, and Warner (1996), the implication in terms of provincial inequality of including a coastal dummy is ambiguous. Indeed, if the coast effect comes from the preferential policies, then their removal will slow down the coastal provinces and maintain existing inequality. However, if the coast effect represents geographical advantage, removal of preferential policies would not halt the rise in provincial inequality. 
Further attempts to account either for the policy factor or for the geographical factor have been made separately by Wang and $\mathrm{Hu}$ (1999) and Bao, Chang, Sachs, and Woo (forthcoming). Since provincial FDI is highly correlated with provincial GDP growth, Wang and Hu's (1999) regressions can be interpreted as provincial growth regressions. Wang and $\mathrm{Hu}$ (1999) distinguish an "economic model," which says that foreign funds flow to areas with the best growth potential (indicated by adequacy of infrastructure, availability of educated workforce, and size of market), from a "policy model," which says that foreign funds flow to areas with the most preferential tax treatment. Their estimations show that the addition of a preferential policy index removes the statistical significance of variables championed by economic model. Coastal growth would thus be more the result of preferential policies than of their more favorable economic conditions. Wang and $\mathrm{Hu}(1999$, ch. 4) discuss in detail the importance of physical terrain in determining economic growth. They also note that their "policy variable may also reflect a province's geographical location." Nevertheless, their policy discussion ignores the geography factor as the main reason for the success of the coastal provinces. Finally, Bao, Chang, Sachs, and Woo (forthcoming) use geographic characteristics to explain differences in provincial economic growth and find that geographical determinism fits the data well. However, they did not show that policy does not matter, especially if policy stance is collinear with geographical location.

Our approach in this paper consists in replacing the black box of regional dummies with two variables:

1. transportation cost and pure geography effect, represented by the proportion of the provincial population in 1994 living within 100 kilometers of the coast or navigable rivers that flow to the sea (excluding the coastline above the winter extent of sea ice and the rivers that flow to this coastline) [Pop $100 \mathrm{cr}]$

2. a preferential policy index for each province [Policy]

The construction of the preferential policy index is based on the number of designated open economic zones in a province and the extent of the preferential treatment. The construction of this index relies on available information on designated open economic zones across China, gathered from different sources, as well as a subjective classification based on their importance in terms of special treatment given to investors and industrial enterprises. Given the various

\footnotetext{
${ }^{33}$ Note that in Zhang (forthcoming), the coastal dummy and export variable are insignificant in $1978-84$ but significant in 1985-95. Zhang explains this difference by the fact that exports (and more generally, international
} 
degrees of preferential policies that open economic zones offer, we gave to their host provinces the following weights:

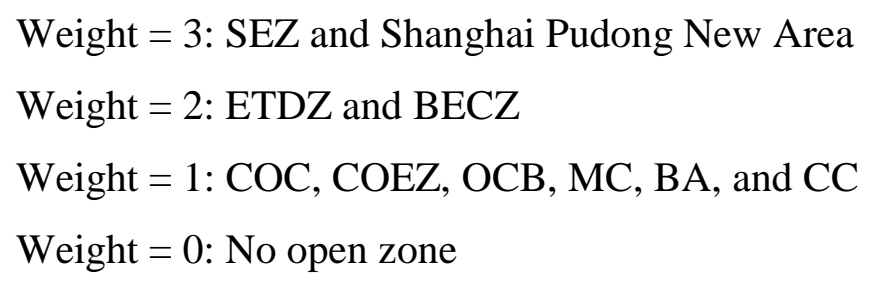

Table 11 reports the results of this scaling. We want to stress that the policy factor is restricted to purely open-door preferential policies and does not take into account other factors, such as the business environment. Moreover, disentangling geography and policy may not be an easy task because preferential treatments are obviously related to geography; for example, one of the main determinants in choosing Shenzhen as a SEZ was its location next to Hong Kong. Fortunately, the correlation between them does not appear to be so close that disentanglement would be a hopeless task. The coefficient of correlation between the average value of the policy index over 1978-98 and the proportion of provincial population in 1994 with easy access to sea transportation $[\mathrm{Pop} 100 \mathrm{cr}]$ is 0.54 .

\section{Estimation results}

Table 12 presents a preliminary decomposition of the effects of geography and policy. Equations 1 through 3 regress the provincial output growth rate in the different subperiods of the reform era on the initial income level and the coast dummy. ${ }^{34}$ This simple formulation produces coefficients with the theoretically expected signs almost all the time: a negative coefficient for initial output level and a positive coefficient for the coast dummy. However, the low t-statistics of the output coefficient mean that conditional convergence does not accurately describe the behavior of provincial output growth in China. The interesting result is that the coefficient of the coast dummy increases markedly in size over the subperiods, from 0.017 in 1979-84 to 0.022 in 1985-91, and then to 0.039 in 1992-98. The growing influence of the coast on output growth is confirmed by the monotonic increase in its t-statistics over time, from 2.98 in 1979-84 to 5.11 in 1992-98.

Equations 4 to 6 in table 12 replace the coast dummy with the Policy variable and the

integration) reached a critical mass to become an important boost to China's economy only after 1985. 
Pop100 cr variable as the proxies for, respectively, provincial access to preferential treatment of foreign investment, and provincial access to water transportation. .5 Roughly speaking, the magnitude of the policy coefficient is stable over time (0.01), while the magnitude of the geography coefficient increases over time (from zero to 0.04 ). As will be confirmed later, this large difference in the temporal profiles of the policy coefficient and the geography coefficient continues to hold in more sophisticated specifications of the provincial growth equations.

The contrasting time profiles of these two coefficients emphasize the intuitively sensible point that the time lag between impact and effect could differ substantially among variables. In such situations, estimations based on averaging the variables over the entire time period or on pooling the data set would understate the coefficients of the slower-acting variables. This point is clearly seen in equations 7 and 8 . The estimated coast coefficient is 0.0267 when the data are averaged over the entire 1979-98 period, and 0.0387 when the data are averaged only over the 1992-98 subperiod; and the estimated geography variable is 0.0145 for $1979-98$ data and 0.0427 for 1992-98 data.

The coast coefficient in 1978-84 is, however, not statistically different from its value in 1992-98: the two standard deviations confidence interval (2SDCI) for them are [0.0057, 0.0289] and [0.0236, 0.0538], respectively. The coefficients for Pop100cr in 1978-84 and 1992-98 are, on the other hand, statistically different from each other, their 2SDCI being [0.0020, 0.0282] and $[0.0307,0.0545]$, respectively. It appears that the reason why the coast coefficient did not vary sufficiently across subperiods is because the Policy coefficient (Policy being a component of coast) was stable across the subperiods. The 2SDCI for the Policy coefficient is [0.0017, 0.0095] in 1978-84 and [-0.0047, 0.0246] in 1992-98. The most important finding, of course, is that the geography coefficient unambiguously increased over time. This finding in table 12 lends credence to the impression given in table 9 that geography is a slow-acting variable.

The fact that the $R^{2}$ is highest in the 1992-98 subperiod means that this particular specification of the provincial growth equation is most valid for this subperiod. We will hence focus our discussion more on the cross-section estimation results from the different subperiods

\footnotetext{
${ }^{34}$ In work not reported here, we found that changes in periodization did not change the character of the results reported in tables 12 and 13 .

${ }^{35}$ To be more accurate, because the values of Pop100cr and Policy are province-specific, we have replaced all the possible regional dummies not just the coastal dummy.
} 
than on those based on averaging the entire time period.

Table 13 reports the estimation results of more complete specifications of provincial growth equations. All of the additional variables received only partial statistical support, and this may reflect the well-known difficulty of estimating parameters reliably when the sample size is small. For example, equations 7, 8, 9, and 12 estimate nine parameters each with a sample of 25 observations.

The initial size of the agricultural sector is included because China's economic reform started with the large-scale deregulation of this sector. A squared term of the agriculture variable is added because Tian (1999) found a diminishing role for agriculture. The agriculture variables have the theoretically expected signs in all twelve cases, and they receive strong statistical support in two cases and satisfactory statistical support in two other cases.

The insertion of the initial size of the state sector variable is based on Sachs and Woo's (1994) argument that the maintenance of the existing state-owned sector would require the state to give state-owned enterprises (SOEs) priority access to capital, raw materials, and skilled manpower, hence making it difficult for new non-state enterprises, like rural industrial enterprises, to emerge. This SOE variable has the theoretically expected sign in most of the cases, and strong statistical support in half of them. Strong statistical support for the SOE variable is always seen in the first subperiod, 1979-84, and this particular confirmation of the Sachs-Woo hypothesis is not surprising because this is the period when the Chinese government was most committed to maintaining the primacy of state ownership in the industrial sector.

The education variable is the proportion of the provincial workforce that had a postprimary education $\frac{37}{}$. Education always had the correct sign, and received strong statistical support in two of the four cases. The transport variable is measured by the density of the roadrailway-canal network. It has the expected sign in two of the four cases, and satisfactory statistical support in only one instance.

The different specifications in tables 12 and 13 yield four common conclusions. First, conditional convergence is only hinted at, rather than statistically supported. In table 13, the initial GDP level has the correct sign in 11 cases out of 12, and strong statistical support in only

\footnotetext{
${ }^{36}$ This is also why we present the results of the pooled regressions as an appendix table and not in the main text. While the pooled regressions yielded parameter estimates that were similar to cross-section regressions on data averaged over the entire 1979-98 period, they had much lower $R^{2}$ values.

${ }^{37}$ Data on education are drawn from Démurger (2001).
} 
one case (equation 12). Second, the Pop100cr coefficient increases in magnitude and statistical significance over time. ${ }^{8}$ Third, the Policy coefficient generally is stable in magnitude across time and receives strong statistical support. Fourth, all the specifications fit the data best in the 1992-98 subperiod (with the $R^{2}$ in table 12 rising from 0.55 in 1979-84 to 0.87 in 1992-98), and we attribute this to the slow-acting nature of geographical forces.

\section{The economic mechanisms of preferential policies and geography}

We constructed the provincial preferential policy index to reflect the extent to which the province had exempted the establishment of foreign-funded enterprises (FFEs), the profits of FFEs, the international trade transactions of FFEs, and the domestic operations of the FFEs from the restrictive state regulations governing the enterprise sector, particularly the foreign enterprise sector. Differences in provincial policies no doubt help to explain the distribution of FDI within China, but this is not a zero-sum game for the country. Collectively, these policies attracted substantial FDI that would have otherwise flowed to other East Asian economies. By government intent and design, the main growth mechanism of the provincial preferential policies is FDI.

Geography, in comparison, manifests itself through two growth mechanisms: FDI and rural industrial enterprises. As most FDI in China is export-motivated, FDI would (ceteris paribus) prefer provinces that provide easier access to sea transportation (which is what the Pop100 cr variable is designed to proxy for). Since a large and growing proportion of China's exports are produced by rural enterprises (in many cases, initially as subcontractors to SOEs and FFEs), it has been natural for these export-oriented rural enterprises to be established in the coastal provinces. It appears that these rural enterprises had generated agglomeration effects and backward economic linkages that induced new rural enterprises (not necessarily export-oriented) to locate themselves in the same localities, thus making the coastal region a major growth area. The opening of trade, in brief, allowed geography to establish FDI and rural industrial enterprises as its main growth mechanisms. Quantitatively, this second mechanism of rural enterprises has been much more important in China's growth. ${ }^{2}$

\footnotetext{
${ }^{38}$ For equations 4 and 6 in table 13, the 2SDCI for Pop 100cr is $[-0.014,0.0208]$ in 1978-84 and [0.0219, 0.0437] in 1992-98; and the 2SDCI for Policy is [-0.001014, 0.0076] in 1978-84 and [0.0010, 0.0212] in 1992-98.

${ }^{39}$ Woo (1998) found that rural industrial enterprises accounted for almost 30 percent of the increase in output during 1985-93.
} 
Table 14 presents the evidence on the proposed economic growth mechanisms of the Policy and Pop100cr variables. Part A of table 14 reports the interrelationship between FDI, Policy and Pop100cr for the 26 provinces analyzed in tables 12 and 13. There are two noteworthy results.

First, the FDI-Policy link is stronger than the FDI-Pop100cr link. The correlation coefficient of FDI-Policy is larger than the correlation coefficient of FDI-Pop100cr for all time periods, suggesting that Policy had a greater influence than Pop100cr in determining the location of FDI. This suggestion is bolstered by the fact that the FDI-Policy correlation coefficient is always strongly statistically significant (with the weakest link at the 0.3 percent significance level in 1985-91), which is not true of the FDI-Pop100cr correlation coefficient.

Second, geography became a bigger determinant in the location decision of FDI over time. The FDI-Pop100cr correlation coefficient rose from 0.23 in 1979-84 to 0.4 in 1985-91, and then to 0.55 in 1992-98. (These figures are still smaller than the smallest FDI-Policy correlation coefficient, 0.66 in 1985-91.) The tightening of the FDI-Pop100cr link over time is likely to be the result of the following:

1. the gradual extension of preferential policies to other provinces, as evidenced by the decline in the coefficient of variation for Policy from 2.8 in 1979-84 to 0.4 in 1992-98 (see part C of table 12) ${ }^{40}$, and

2. geography having a longer lag on FDI compared to Policy (which may explain the difference in the temporal profiles of Pop100cr and Policy on provincial income growth that we had identified in tables 9,12 and 13).

Part B of table 14 supports our hypothesis that geography also influences the location of rural enterprises, the most important engine of growth since 1984 (Woo 1998). The typical coastal province employed a larger proportion of the workers employed in rural enterprises nationwide (6.5 percent) compared to its endowment of labor resources ( 4.7 percent) and compared to its share of employment in the SOE sector (4.3 percent). While the disproportionately higher concentration of FFE employment in the typical coastal province (10.7 percent) could be "blamed" on the preferential policies extended to it, the disproportionately

\footnotetext{
${ }^{40}$ When many regions could offer virtually the same incentive package to FDI, transportation costs naturally become more important in the considerations of the foreign investors.
} 
higher concentration of rural enterprise employment cannot be attributed to the preferential policies.

Our hypothesis of the coastal provinces being "geographically advantaged" for growth is also supported by the provincial distribution of investment within each type of enterprise form. The typical province in the coastal region has a higher share of the total rural enterprise investment and of the total FFI investment (10 percent and 8 percent, respectively) compared to its share of total national investment and total SOE investment (7 percent and 6 percent, respectively).

To make our point that FDI is one of the economic growth mechanisms enabled by the Policy and Pop100cr variables, table 15 reports the regression results of adding FDI into our preferred specification in table 13. FDI received strong statistical support in only one of the four cases, and its presence reduced the t-statistics of Policy and Pop100cr in every case. The transformation of the Policy coefficient into statistical insignificance by the inclusion of FDI most likely reflects the strong multicollinearity between these two variables documented in part A of table 14. The results in table 15, therefore, are consistent with our hypotheses that (a) FDI into China and its distribution within China has largely been induced by Policy and Pop100cr, and (b) the growth of the rural industrial sector has been accelerated by Pop100cr.

\section{Conclusion}

During the central planning period, the high and increasing degree of provincial income inequality reflected the unusually high per capita income of Beijing, Shanghai, and Tianjin, and the growing income gap between these three metropolises and the rest of the country. Shanghai stayed unchallenged at the top of the provincial income ranking during the entire 1952-78 period. Beijing moved from ninth place in 1952 to second place in 1978; Tianjin moved from fourth to third. This revealed that the urban bias of China's central planners was in reality an obsession with industrialization that was passed on by their Soviet mentors. This policy favoritism toward the industrial sector is nicely illustrated by the fact that the industrial heartland provinces of Heilongjiang and Liaoning held the fourth and fifth places, respectively, in the 1978 ranking of provincial income.

The central plan suppressed agricultural prices and exaggerated industrial prices to generate investment funds for the industrial sector. Agricultural collectivization, while 
recommended on ideological grounds, facilitated the extraction of the agricultural surplus for industrial investment. The tragedy of the Great Leap Forward experiment was, arguably, the result of taking the Soviet religion of industrialism one step too far.

The combination of low agricultural prices, high taxation, and the badly flawed "work point" compensation system kept agricultural productivity growth low and, hence, rural income growth low. The whole economic system was structured by central planning to produce a wide and growing urban-rural income gap. This is why, before 1979, Cov28 in figure 1 was much higher than Cov25, and displayed an upward trend relative to Cov25. 11

With the reintroduction of markets and the reintegration of the economy into the world system beginning in 1979, additional factors have emerged to affect the distribution of provincial income. They include, among others, the sequence of the economic reforms, the changes in fiscal policy, the selective spatial relaxation of the regulations restricting foreign investment, and the geographical location of the province. Large-scale deregulation was introduced first to the agricultural sector. At the same time, there were cutbacks in state investment in the inland provinces and cutbacks in state subsidies to the poorer provinces - the two types of provinces that were disproportionately agricultural in orientation. Still, the overall impact of these policy changes on the agricultural provinces was positive in 1978-84. The agricultural boom narrowed the urban-rural income gap, causing Cov28 and Cov25 in figure 1 to fall during this period.

In 1984, the state began to relax the restrictions on export activities and on the establishment of non-state industrial enterprises in rural areas, and to extend the preferential policies on FDI from the southern coastal provinces to other coastal provinces. Large numbers of rural enterprises and foreign-funded enterprises started sprouting up in the coastal provinces, notably in Guangdong, Zhejiang, Jiangsu, and Shangdong. It was very fortunate for these coastal provinces that these policy changes took place at that time.

By 1984, the agricultural sector was beginning to reach the limit of the benefits created by the substantial (but still partial) deregulation of agriculture during 1979-82. These new policy changes regarding exports, non-state enterprises, and foreign-funded enterprises thus encouraged the coastal agricultural provinces to switch their engine of growth from farming to rural industries, just when the one-shot agricultural productivity growth impetus had spent its

\footnotetext{
${ }^{41}$ Cov2 8 is the coefficient of variation for the per capita income of 28 provinces. Cov25 is calculated after excluding Beijing, Shanghai, and Tianjin from the sample used for calculating Cov28.
} 
force. Lacking the same linkage opportunities to foreign-funded enterprises, and facing higher costs in transporting goods to foreign markets, the rural enterprise sector in the inland provinces did not take off as it did in the coastal provinces. The inland agricultural provinces hence continued to rely mainly on farming, the flagging engine of growth, as its main economic activity.

During the 1985-89 period, the coastal agricultural provinces continued their race to catch up with the three metropolises and the traditionally rich Manchurian provinces. The noncoastal agricultural provinces either kept pace with the Manchurian provinces or started lagging behind them again. ${ }^{2}$ These differences in performance among the agricultural provinces vis-à-vis the industrial provinces are responsible for the minor movements of Cov28 and Cov25 in 1985-89, shown in figure 1.

Liaoning's ranking in provincial GDP per capita was overtaken by Guangdong in 1992, by Zheijiang in 1994, and by Jiangsu in 1995. By 1995, Fujian's GDP per capita was less than 2 percent below that of Liaoning. The important point is that these four coastal provinces continued growing faster than Liaoning in the subsequent 1996-99 period (see part A of table 16). When the average 1996-99 growth rate of the six provinces in table 16 is regressed on the 1995 GDP level and a coast dummy, the respective coefficients are -0.0011 and 3.86, with respective absolute t-statistics of 2.4 and 4.0 .4 The presence of conditional income convergence, but not unconditional income convergence, in these six provinces is in line with the regression results in tables 12 and 13. In brief, the 1992-98 period is characterized by the newly rich coastal provinces continuing to grow faster than the traditionally rich northeastern provinces, and the still-backward northwestern and southwestern provinces growing at about the same or lower pace than the northeastern provinces. The result is a divergence in provincial incomes in the 1990s that caused Cov28 and Cov25 in figure 1 to rise to unprecedented levels.

In part B of table 16, we use the average values of the estimated coefficients of Pop100cr and Policy from equation 6 in table 12, and equations 6 and 9 in table 13, to quantify the contributions of geographical location and preferential policies to the growth rates of provinces in the different regions. In the 1996-99 period, the growth rate of the typical coastal province

\footnotetext{
${ }^{42}$ For example, Fujian (coastal) moved from seventeenth place in 1978 to tenth place in 1991; Heilongiang (northeastern) fell from fourth in 1978 to fifth in 1984 and then to seventh in 1991; and Hubei (central), which had risen from eighteenth in 1978 to fifteenth in 1984, fell back to eighteenth in 1991. See table 6.

${ }^{43} \mathrm{~A}$ constant term was included in the regression.
} 
benefited about equally from its geographical location (2.84 percentage points) and preferential polices (2.83 percentage points). The level of each type of benefit received by the coastal provinces was higher than the level received by provinces in other regions. Thanks to the navigable portions of the Yellow River and the Yangtze River, a central province received a boost of 1.99 percentage points to its growth rate, which is higher than the boost from preferential policies, 1.56 percentage points. Compared to a northwestern or a southwestern province, a northeastern province was more favored by geography and preferential policies.

The growth decomposition yields two important observations for economic policy. First, the faster growth of the coastal provinces could not be largely attributed to the more preferential policies that they had received. The coastal location was as important as the preferential policies in promoting growth. Second, despite the significant easing of regulations on FDI and international trade in the interior provinces since 1992, the difference in the level of deregulation ("preferential treatment") in 1996-98 was still quite large, causing a one percentage point gap between the coastal provinces and the central, northwestern, and southwestern provinces. The average preferential policy index value in 1996-99 was 2.0 for the typical northeastern province, 2.4 for the typical coastal province, 1.3 for the typical central and northwestern province, and 1.5 for the typical southwestern province.

We should note that the metropolises (with province-level status, excluding Chongqing) are definitely more "preferred" than the coastal provinces. The preferential policy index value for the typical metropolis in this period was 3.0, higher than any of the regional groups. GDP per capita of the average metropolis grew 9.88 percent in 1996-99, with 2.45 percentage points contribution from Popl00cr and 3.50 percentage points from Policy.

If the preferential policies directed toward FDI had been absent for all provinces in 199699, the central provinces would have shown the highest growth rates (8.73 percent), but the coastal provinces would still have grown faster than the northeastern, northwestern, and southwestern provinces. Furthermore, because the preferential policies had a positive impact on the growth of the inland provinces, the elimination of preferential policies to equalize policy treatment of the provinces would have been a negative shock to the inland provinces. Since the troubling aspect about the preferential policies was not their effectiveness, but the unequal access to them, the solution lies in increasing the access of the inland provinces to the preferential policies rather than in denying these policies to everyone. The central government acted 
correctly in the last two years when it reduced its preferential treatment of the coastal SEZs, not by removing the various tax and foreign exchange exemptions that they could grant to FDI, but by allowing the inland economic zones to extend these same exemptions to FDI. Part B of table 16 gives the counterfactual growth scenario for the case where Policy $=2$, the index value for the northeastern provinces, for all provinces. The outcome would have been a higher GDP growth rate and a reduction in the coefficient of variation for provincial income (as incomes of the poorer provinces increase faster, with a 0.5 percentage point decline in the growth rates of coastal provinces).

The presence of only conditional convergence and not unconditional convergence in China stands in marked contrast with Barro and Sala-Martin's finding of unconditional convergence in the United States. We attribute this difference between the United States and China, primarily, to China's household registration system, and, secondarily, to its incomplete reform of the state bank system. Under the household registration system, only approved people have the right to live and work permanently in urban areas, and receive publicly provided social services such as education and medical care. The police issue residence permits (hukou) to the approved people. Because residence status is largely determined by place of birth, ${ }^{44}$ the hukou system in effect denies the poor the possibility of getting a higher-paying job legally by moving to the prosperous cities. The U.S. experience suggests that gradual movements in population over the last century away from the northern plains to the two coasts was fundamental to the working of the income convergence process. China's hukou system was therefore likely to have been a major reason for the increase in provincial inequality.

While international experiences indicate that labor tends to flow from the poor regions to the rich regions, they also indicate (unfortunately) that capital has a less reliable tendency to flow from high-wage areas to low-wage areas. In not a small number of cases, capital actually flowed from the low-wage to the high-wage areas. ${ }^{45}$ In some of these "perverse" cases, this reverse flow could be traced to the already prosperous urban centers being the centers of endogenous growth, where continual technological innovations kept the rate of return to investment high. The implication is that when China's metropolises and other large coastal cities do develop into

\footnotetext{
44 This is conditional upon the parents being legal residents of that place at the time of birth.

${ }^{45}$ A glaring example in the international context would be the large net capital inflows to the United States in the last twenty years.
} 
endogenous growth centers in the future, labor mobility is the only easy solution to slow (or reverse) the increase in regional inequality.

Since China's metropolises and other coastal cities are not yet centers of endogenous growth, the reason for the trickle of capital ${ }^{16}$ from the coast to the interior obviously lies elsewhere. It lies in the monopoly state bank system and in the continued existence of lossmaking SOEs. By using up a large portion of the private saving deposits in the banking system to prop up the inefficient SOEs, the government has hindered the establishment of new businesses everywhere, including those in the interior provinces. The state banks have contributed to regional inequality because they are non-profit-maximizing, and, out of bureaucratic inertia, bureaucratic ease, and bureaucratic fear of risk, they have allocated the leftover capital to their traditionally biggest customers, the SOEs on the coast and in the northeast.

The crucial point here is that there are many important factors that contributed to the widening of regional disparity. Besides being geographically disadvantaged, the interior provinces could not shed the labor in their low-productivity agriculture sectors because of the hukou system; they were denied access to capital because of the bureaucratic nature of the state banks; and they faced more stringent regulations governing FDI and international trade. Accordingly, given the wide array of causes, the appropriate policy response has to be a multifaceted one. The "good" news is that there are some quick fixes available to ameliorate the situation. Two of the three man-made factors- the hukou system and anti-internationalization regulations - could be eliminated overnight in order to help the income convergence process to work.

The flaws of the state bank system will take longer to fix because in addition to interest rate deregulation and the easing of entry into the bank sector, an effective system of prudential supervision has to be established. The barriers to abating the distance between the different levels of steady-state provincial incomes created by geography will take even longer to fix. Large-scale infrastructure projects such as roads and railways would definitively help in reducing geography-related constraints and should be targeted to facilitate transactions and reduce transportation costs, even if better communications in the northwestern provinces might end up facilitating the relocation of their residents to the coast more than encouraging the migration of

\footnotetext{
${ }^{46}$ Excluding the recent large capital inflow for infrastructure construction.
} 
coastal firms to the northwest. The relevant consideration is that this labor movement will improve the welfare of the rural poor in the interior provinces.

The government clearly recognizes the great importance of providing infrastructure to overcome production bottlenecks and facilitate international economic integration. Infrastructure construction stands first in the following list of priority tasks in the strategy to develop the western provinces (State Council 2000):

- developing infrastructure

- improving and protecting the environment

- strengthening agriculture

- restructuring industry

- promoting tourism

- enhancing science, technology, education, and public health

While infrastructure investment could reduce regional disparity, the development strategy for the interior provinces has to be more creative than simply building clones of Shenzhen in the northwestern and southwestern provinces. The development problem is clearly more complicated than that; hence we feel that science, technology, education, and public health has been given too low a ranking in the above priority list. This concern stems from our belief that, once a market economy is in place, technological advancement is the fundamental engine of sustainable development. The ultimate prize of western development efforts is the successful incubation of two or three centers of endogenous growth in western China. If the incubation effort is too ambitious, the next objective is to create sufficient local scientific capacity to hasten the diffusion of new technologies from the coastal provinces and foreign countries to western China. Because education lies at the heart of the ability to acquire and innovate new technologies, it should not be at the bottom of the priority list.

Even in the worst case scenario, in which neither technological innovation centers nor technological diffusion centers could be successfully established, good education and good health would enable individuals who migrate to the coastal provinces to get higher-paying jobs and contribute to the technological progress there. Compared to physical capital formation, human capital formation has a much lower wastage rate because humans can move and bridges and tunnels cannot.

The high priority that the State Council (2000) has accorded to environmental protection 
is farsighted. The high priority given to agricultural development is certainly correct because the bulk of the population in the western and central provinces is still engaged in agricultural production. It is important, however, that agriculture be strengthened not just by provision of physical infrastructure but also by agriculture-related technology transfers, such as the following:

1. the development of new varieties of local crops that have higher yields, are more diseaseresistant, and require less water to grow;

2. the improvement of the local livestock through cross-breeding, and through better access to veterinarian services; and

3. the development of new processed food products from the local agricultural base. It needs re-emphasizing that the causes of regional inequality are many. The frequent lone focus on the role of preferential policies is really not justified, even though it is understandable because the term "preferential" smacks of undeserved transfers. Geographical factors have been quantitatively just as important as preferential policies in the growth of the coastal provinces, and yet while there have been many discussions about removing these preferential policies, there have not been enough discussions about solving the geographic barriers to growth in the interior provinces. Just as the talk about removing the preferential policies is wrongheaded because the more sensible step is to extend what are really deregulation policies to the rest of the country, the talk about increasing physical capital formation to overcome geographic barriers is inadequate, because only human capital formation can come up with better solutions to these centuries-old problems. Bringing in science to bear on the growth of the western provinces is only one aspect of the multi-pronged approach required to ameliorate regional disparity. There are many more aspects that require careful study, for example, the forms of urbanization that would be most effective in generating growth in different areas within western China. We hope to discuss this and other important topics in future papers. 


\section{References}

Ahmad, Ehtisham, Li Keping, and Thomas Richardson. 2000. Recentralization in China? Paper presented at the International Monetary Fund conference, Fiscal Decentralization, 20-21

November, Washington, D.C.

Aziz, Jahangir, and Christoph Duenwald. 2001. China's Provincial Growth Dynamics. IMF Working Paper WP/01/3. Washington, D.C.: International Monetary Fund.

Bao, Shuming, Gene Chang, Jeffrey D. Sachs, and Wing Thye Woo. forthcoming. Geographic Factors and China's Regional Development Under Market Reforms, 1978-98. China Economic Review.

Berthélemy, Jean-Claude, and Sylvie Démurger. 2000. Foreign Direct Investment and Economic Growth: Theoretical Issues and Empirical Application to China. Review of Development Economics 4 (2):140-55.

Bloom, David, and Jeffrey D. Sachs. 1998. Geography, Demography, and Economic Growth in Africa. Brookings Papers on Economic Activity 2:207-73.

Chan, Roger C.K., Tien-Tung Hseuh, and C. Luk (eds.). 1996. China's Regional Economic Development. Hong Kong: Hong Kong Institute of Asia-Pacific Studies, Chinese University of Hong Kong.

Chen, Baizhu, and Yi Feng. 2000. Determinants of Economic Growth in China: Private Enterprise, Education and Openness. China Economic Review 11 (1):1-15.

Chen, Jian, and Belton M. Fleisher. 1996. Regional Income Inequality and Economic Growth in China. Journal of Comparative Economics 22 (2):141-64.

Chen, Yisheng, 2000. On the Development of Economic and Technological Zones in China. Beijing: Chinese Academy of Sciences. http://www.ced.bg/eng/projects/project11/calendar/iasp2000/index.html.

Chen, Yu. Forthcoming. Decentralization, Local Provision of Public Goods and Economic Growth: The Case of China. In Sustainability of China's Economic Growth in the 21st Century, edited by Ross Garnaut and Ligang Song. Canberra, Australia: Asia Pacific Press.

Cheung, Peter T.Y., Jae Ho Chung, and Zhimin Lin (eds.). 1998. Provincial Strategies of Economic Reform in Post-Mao China: Leadership, Politics, and Implementation. Armonk, New York: M.E. Sharpe.

Dayal-Gulati, Anuradha, and Aasim M. Husain. 2000. Centripetal Forces in China's Economic Take-off. IMF Working Paper WP/00/86. Washington, D.C.: International Monetary Fund.

Démurger, Sylvie. 2000. Economic Opening and Growth in China. Paris: OECD Development Centre Studies. 
Démurger, Sylvie. 2001. Infrastructure Development and Economic Growth: An Explanation for Regional Disparities in China? Journal of Comparative Economics 29 (1):95-117.

Diamond, Jared. 1997. Guns, Germs and Steel: The Fates of Human Societies. New York: W.W. Norton \& Company.

Engerman, Stanley, and Kenneth Sokoloff. 1997. Factor Endowments, Institutions and Differential Paths of Growth among the New World Economies. In How Latin America Fell Behind, edited by Stephen Haber. Stanford: Stanford University Press.

Fleisher, Belton M., and Jian Chen. 1997. The Coast-Noncoast Income Gap, Productivity and Regional Economic Policy in China. Journal of Comparative Economics 25 (2):220-36.

Fujita, Masahisa, and Dapeng Hu. 2001. Regional Disparity in China 1985-94: The Effects of Globalization and Economic Liberalization. Annals of Regional Science 35 (1): 3-37.

Gallup, John Luke, Jeffrey D. Sachs, and Andrew Mellinger. 1999. Geography and Economic Development. International Regional Science Review 22 (2):179-232.

Gilley, Bruce. 1998. Tiger on the Brink: Jiang Zemin and China's New Elite. Berkeley: University of California Press.

Gundlach, Erich. 1997. Regional Convergence of Output per Worker in China: A Neoclassical Interpretation. Asian Economic Journal 11 (4):423-42.

Hall, Robert E., and Charles Jones. 1999. Why Do Some Countries Produce So Much More Output per Worker Than Other Countries? Quarterly Journal of Economics 114 (1):83-116.

Jian, Tianlun, Jeffrey D. Sachs, and Andrew M. Warner. 1996. Trends in Regional Inequality in China. China Economic Review 7 (1):1-21.

Kamarck, Andrew. 1976. The Tropics and Economic Development. Baltimore: The Johns Hopkins University Press.

Kanbur, Ravi and Xiaobo Zhang. 2001. Fifty Years of Regional Inequality in China: A Journey Through Revolution, Reform and Openness. Cornell University. Unpublished manuscript.

Landes, David. 1998. The Wealth and Poverty of Nations: Why Some Are So Rich and Some So Poor. New York: W.W. Norton \& Company.

Lane, Kevin. 1998. One Step Behind: Shaanxi in Reform, 1975-1995. In Provincial Strategies of Economic Reform in Post-Mao China: Leadership, Politics, and Implementation, edited by Peter T.Y. Cheung, Jae Ho Chung, and Zhimin Lin. Armonk, New York: M.E. Sharpe. 
Lee, Douglas. 1957. Climate and Economic Development in the Tropics. New York: Harper, for the Council on Foreign Relations.

Lee, Jongchul. 1994. Regional Differences in the Impact of the Open Door Policy on Income Growth in China. Journal of Economic Development 19 (1):215-34.

Lemoine, Francoise. 2000. FDI and the Opening Up of China's Economy. Centre d'Etudes Prospectives et d'Informations Internationales (CEPII). Paris.

Li, Hong, Zinan Liu, and Ivonia Rebelo. 1998. Testing the Neoclassical Theory of Economic Growth: Evidence from Chinese Provinces. Economics of Planning 31:117-32.

Lin, Justin Y., Fang Cai, and Zhou Li. 1999. Social Consequences of Economic Reform in China: An Analysis of Regional Disparity in the Transition Period. Beijing University. Unpublished manuscript.

Lin, Songhua. 2001. International Trade, Location and Wage Inequality. University of California, Davis. Unpublished manuscript.

Lyons, Thomas P. 1991. Interprovincial Disparities in China: Output and Consumption, 19521987. Economic Development and Cultural Change 39 (3):471-506.

Ma, Jun. 1999. The Chinese Economy in the 1990s. Basingstoke: Palgrave Publishers Ltd.

Mao, Zedong. 1956. On Ten Major Relationships. In vol. 5, Selected Works of Mao Tsetung. Beijing: People's Press.

Mody, Ashoka, and Fang-Yi Wang. 1997. Explaining Industrial Growth in Coastal China: Economic Reforms ... and What Else? The World Bank Economic Review 11 (2):293-325.

National Bureau of Statistics (NBS). 1999a. Comprehensive Statistical Data and Materials on 50 Years of New China. Beijing: China Statistics Press.

_. 1999b. China Statistical Yearbook 1999. Beijing: China Statistics Press.

—. 2000. China Statistical Yearbook 2000. Beijing: China Statistics Press.

Naughton, Barry. 1999. Provincial Economic Growth in China: Causes and Consequences of Regional Differentiation. University of California, San Diego. Unpublished manuscript.

Raiser, Martin. 1998. Subsidising Inequality: Economic Reforms, Fiscal Transfers and Convergence across Chinese Provinces. Journal of Development Studies 34 (3):1-26.

Sachs, Jeffrey D., and Wing Thye Woo. 1994. Structural Factors in the Economic Reforms of China, Eastern Europe, and the Former Soviet Union. Economic Policy 18 (April):101-45. 
50 .

State Council. 2000. Circular of the State Council on Policies and Measure Pertaining to the Development of the Western Region. Beijing: China Planning Press.

State Statistical Bureau (SSB). 1997a. The Gross Domestic Product of China, 1952-1995. Dalian, China: Dongbei University of Finance and Economics Press.

_. 1997b. China Statistical Yearbook 1997. Beijing: China Statistical Publishing House. 1998. China Statistical Yearbook 1998. Beijing: China Statistical Publishing House.

Tian, Xiaowen. 1999. China's Regional Economic Disparities Since 1978: Main Trends and Determinants. East Asian Institute Occasional Paper 21. Singapore: National University of Singapore.

- 2001. Privatization and Economic Performance: Evidence from Chinese Provinces. Economic Systems 25 (1):1-13.

Tsui, Kai-yuen.1993. Decomposition of China's Regional Inequalities. Journal of Comparative Economics 17 (3):600-27.

- 1996. Economic Reform and Interprovincial Inequalities in China. Journal of Development Economics 50 (2):353-68.

Wang, Shaoguang, and Angang Hu. 1999. The Political Economy of Uneven Development, The Case of China. Armonk, New York: M. E. Sharpe.

Wei, Yehua Dennis. 2000. Regional Development in China - States, Globalization, and Inequality. London: Routledge.

Wong, Christine P.W., Christopher Heady, and Wing Thye Woo. 1995. Fiscal Management and Economic Reform in the People's Republic of China. Oxford: Oxford University Press.

Woo, Wing Thye. 1998. Chinese Economic Growth: Sources and Prospects. In The Chinese Economy, edited by Michel Fouquin and Francoise Lemoine. London: Economica. Translated into Chinese as "Zhongguo Quan Yaosu Shengchan Lu: Laizi Nongye Bumen Laodongli Zai Pei Zhi de Shouyao Zuoyong" in Jingji Yanjiu, vol. 3, 1998.

- 2001. Recent Claims of China's Economic Exceptionalism: Reflections Inspired by WTO Accession. China Economic Review 12 (2-3):107-36.

World Bank. 1997. Sharing Rising Incomes: Regional Disparities in China. Washington, D.C.: The World Bank. 
Wu, Yanrui. 1999. Income Disparity and Convergence in China's Regional Economies. University of Western Australia Discussion Paper 9915, available on the following site: http://www.econs.ecel.uwa.edu.au/economics/dpapers/DP1999/DP1999.HTM

- 2000. The Determinants of Economic Growth: Evidence from a Panel of Chinese Provinces. Paper presented at the conference, China: Growth Sustainability in the 21st Century, Australian National University, 9-10 September.

Yang, Dali L. 1997. Beyond Beijing_Liberalization and the Regions in China. London: Routledge.

Zhang, Tao, and Heng-fu Zou. 1998. Fiscal Decentralization, Public Spending, and Economic Growth in China. Journal of Public Economics 67:221-40.

Zhang, Wei. Forthcoming. Rethinking Regional Disparity in China. Economics of Planning.

Zhang, Zongyi, Aying Liu, and Shujie Yao. 2001. Convergence of China's Regional Incomes, 1952-1997. China Economic Review 12 (2/3):243-58.

Zhao, Xiaobin. 1996. Spatial Disparities and Economic Development in China, 1953-92: A Comparative Study. Development and Change 27(1). 
Figure 1. $\sigma$-convergence across Chinese provinces

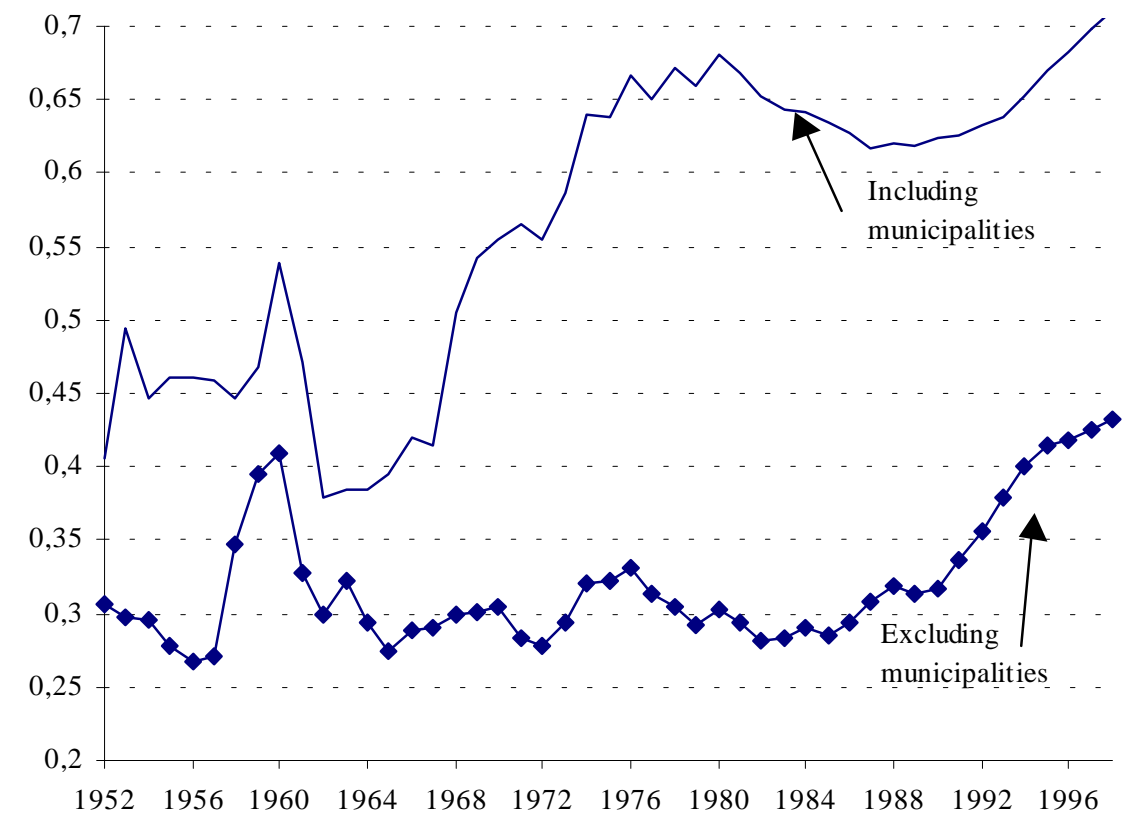

Notes: Hainan and Tibet are excluded due to missing data. Sichuan province includes Chongqing. GDP per capita is calculated at constant 1995 prices.

$\sigma$-convergence is measured by the coefficient of variation.

Sources: NBS (1999a), except for Sichuan, for which sources are SSB (1997a, 1997b, 1998), and NBS (1999b). 
Figure 2. Unconditional $\beta$-convergence, 1953-78 and 1979-98
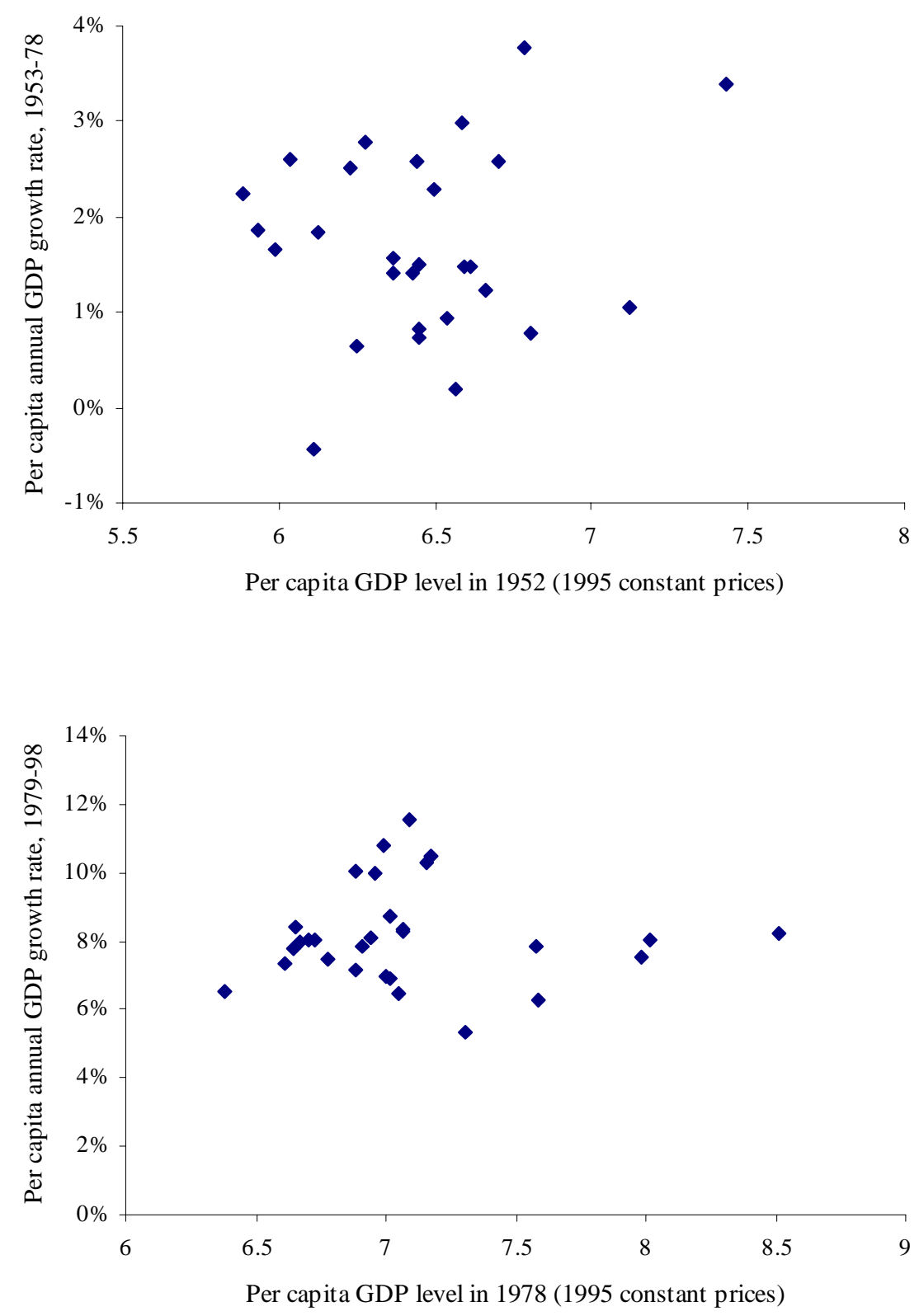

Sources: See Figure 1. 


\section{Table 1. Coefficient of variation of GDP per capita}

\begin{tabular}{lcc}
\hline & $\begin{array}{c}\frac{\mathbf{C O V 2 8}}{(28 \text { provinces })} \\
\frac{\text { COV25 }}{(25 \text { provinces })}\end{array}$ \\
\hline Average 1952-1965 & 0.442 & 0.313 \\
Average 1966-1978 & 0.570 & 0.302 \\
Average 1979-1989 & 0.642 & 0.297 \\
Average 1990-1998 & 0.659 & 0.387 \\
\hline
\end{tabular}

COV28 is the coefficient of variation for 28 provinces (Tibet, Hainan were excluded, and Chongqing was included in Sichuan).

COV25 is the coefficient of variation for 25 provinces (COV28 minus Beijing, Tianjin, and Shanghai). 
Table 2. Geographical characteristics by regions

\begin{tabular}{|c|c|c|c|c|c|c|c|c|c|c|c|c|}
\hline Region & $\begin{array}{c}\text { GDP per } \\
\text { capita } \\
\text { growth rate } \\
(\%)\end{array}$ & $\begin{array}{c}\text { GDP per } \\
\text { capita level in } \\
1978 \\
\text { (yuan/person) }\end{array}$ & $\begin{array}{c}\begin{array}{c}\text { Population } \\
\text { density }\end{array} \\
\text { (person } / \mathrm{km}^{2} \text { ) }\end{array}$ & $\begin{array}{c}\text { Distance } \\
\text { from the } \\
\text { coast } \\
(\mathrm{km})\end{array}$ & $\begin{array}{c}\text { Pop100km } \\
\text { (\% of } \\
\text { population) }\end{array}$ & $\begin{array}{c}\text { Pop100cr } \\
\text { (\% of } \\
\text { population) }\end{array}$ & $\begin{array}{c}\text { Slope }>10 \\
(\% \text { of } \\
\text { area })\end{array}$ & $\begin{array}{c}\begin{array}{c}\text { Average } \\
\text { slope }\end{array} \\
(\%)\end{array}$ & $\begin{array}{c}\begin{array}{c}\text { Average } \\
\text { elevation }\end{array} \\
\text { (meters) }\end{array}$ & $\begin{array}{c}\text { Temperature } \\
\text { (Degrees) }\end{array}$ & $\begin{array}{c}\text { Rainfall } \\
(\mathrm{mm})\end{array}$ & $\begin{array}{c}\begin{array}{c}\text { Arable } \\
\text { land }\end{array} \\
(\%)\end{array}$ \\
\hline Metropolises & 8.5 & 3,645 & 1,104 & 77 & 65 & 71 & 1.4 & 1.2 & 135 & 10.9 & 63 & 36 \\
\hline Northeast & 7.9 & 1,700 & 138 & 380 & 17 & 18 & 2.2 & 1.6 & 314 & 4.5 & 50 & 21 \\
\hline Coast & 10.7 & 1,154 & 333 & 86 & 60 & 82 & 2.6 & 2.4 & 267 & 16.4 & 103 & 29 \\
\hline Central & 8.4 & 941 & 264 & 492 & 0 & 57 & 2.7 & 2.4 & 428 & 14.9 & 90 & 24 \\
\hline Northwest & 7.7 & 1,045 & 46 & 1,383 & 0 & 0 & 5.0 & 2.8 & 1,971 & 6.8 & 26 & 8 \\
\hline Southwest & 7.8 & 814 & 126 & 656 & 4 & 4 & 14.1 & 5.2 & 1,428 & 16.0 & 98 & 10 \\
\hline Total & 9.0 & 1,355 & 290 & 547 & 24 & 41 & 4.3 & 2.7 & 804 & 12.2 & 74 & 21 \\
\hline
\end{tabular}

Notes: GDP per capita compound annual growth rate throughout 1979-98 and GDP per capita levels in 1978 are calculated at 1995 constant prices. Pop100cr = proportion of the population distribution of a province in 1994 within $100 \mathrm{~km}$ of the coastline or ocean-navigable river, excluding coastline above the winter extent of sea ice and the rivers that flow to this coastline. Pop 100km = proportion of the population distribution of a province in 1994 within $100 \mathrm{~km}$ of the coastline, excluding coastline above the winter extent of sea ice. Slope $>10$ measures the percentage of area within a province with a slope greater than $10 \%$. Temperature and rainfall are averages throughout the $1951-88$ period. Arable land is available for 1994.

Metropolises = Beijing, Tianjin, and Shanghai.

Northeast $=$ Liaoning, Jilin, and Heilongjiang.

Coast $=$ Hebei, Jiangsu, Zhejiang, Fujian, Shandong, Guangdong, and Hainan

Central = Shanxi, Anhui, Jiangxi, Henan, Hubei, and Hunan.

Northwest = Inner Mongolia, Shaanxi, Gansu, Qinghai, Ningxia, and Xinjiang (Tibet is excluded due to missing data).

Southwest $=$ Sichuan, Guizhou, Yunnan, and Guangxi.

Sources: NBS (1999) for economic and population variables; GIS calculations made by Bao Shuming for geographical data, except arable land; Wang and Hu (1999, table 4.1, p. 83) for arable land. 
Table 3. Timeline of China's regional preferential policies, 1979-94

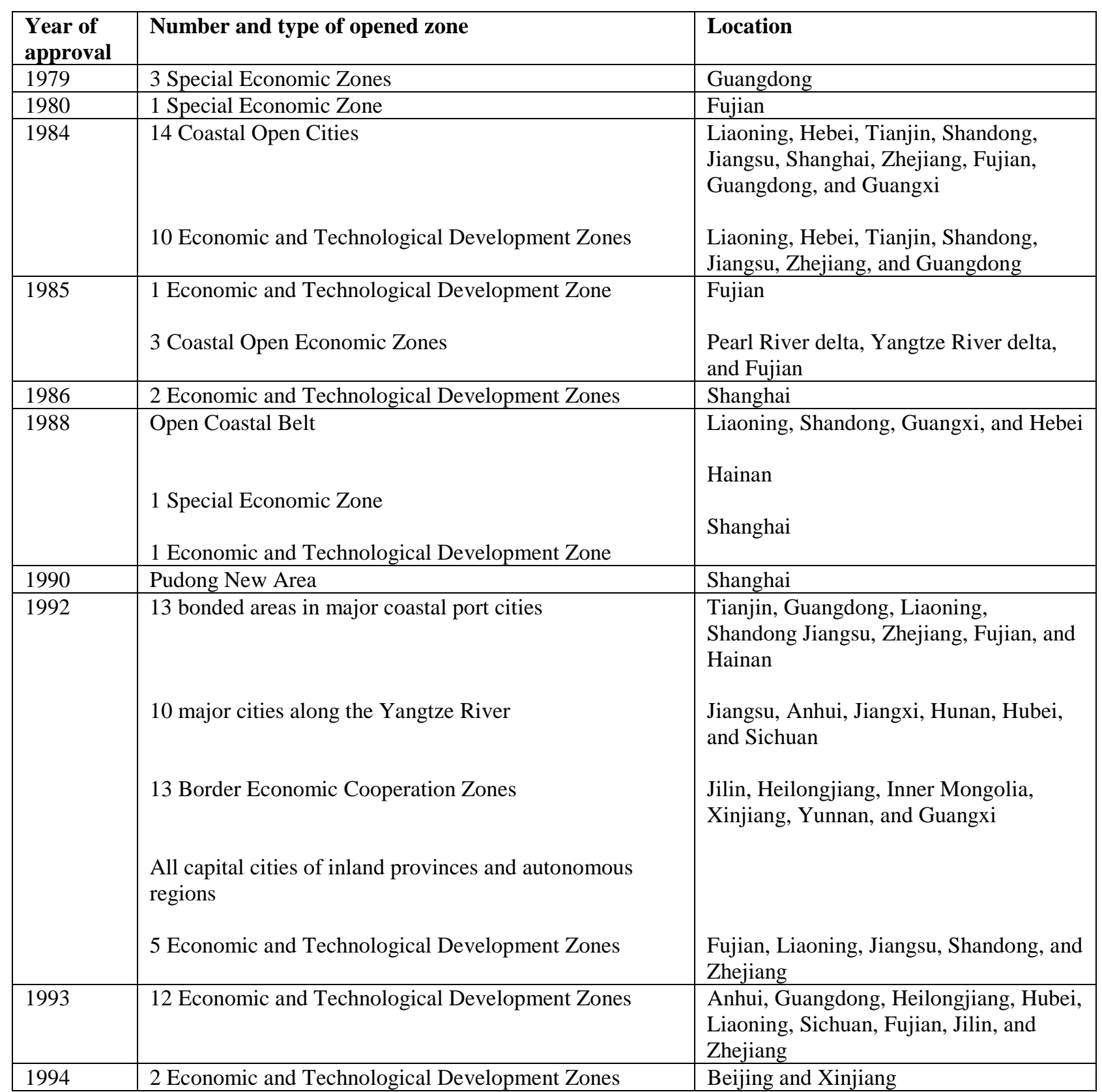


Table 4. Growth episodes by region

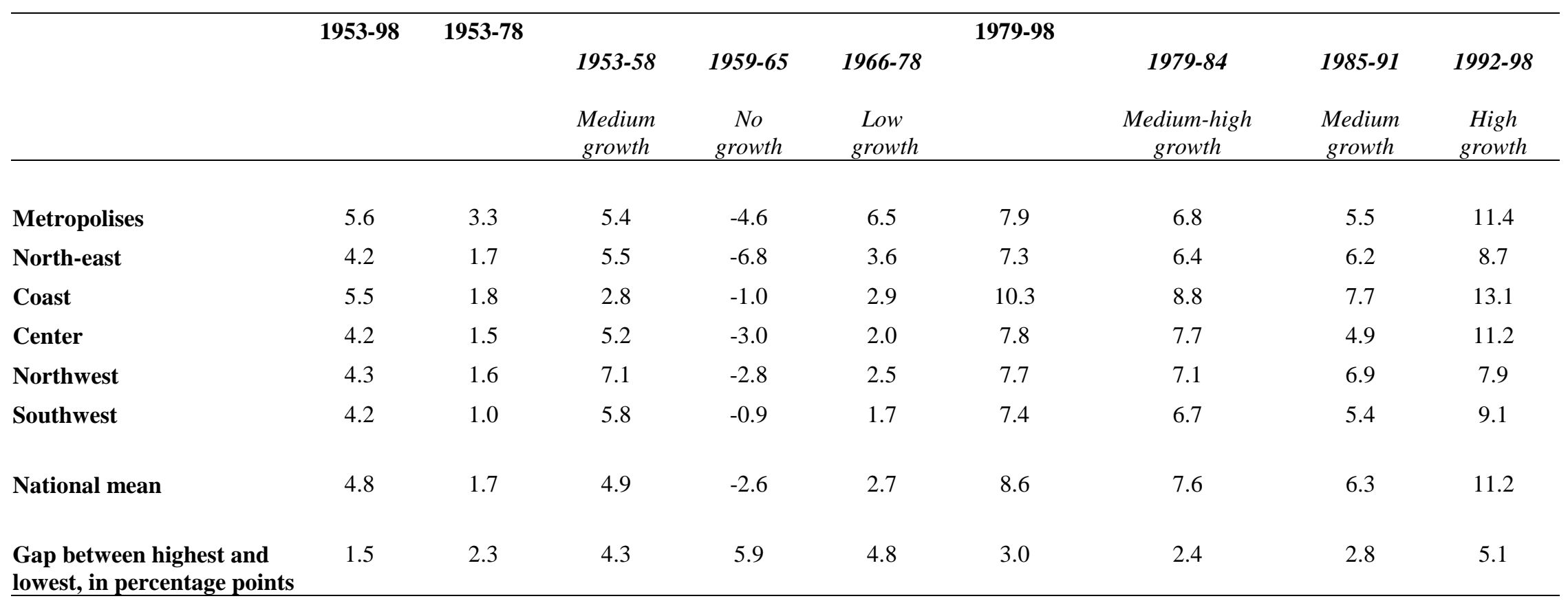

Note: Average annual growth rates are calculated by regressing the logarithm of per capita GDP on a time trend. GDP per capita is measured at 1995 constant prices. Tibet is not included due to missing data for GDP components.

Sources: See Figure 1. 
Table 5. Average annual growth rates of GDP per capita

\begin{tabular}{|c|c|c|c|c|c|c|c|c|c|}
\hline & \multirow[t]{2}{*}{ 1953-98 } & \multicolumn{4}{|c|}{ 1953-78 } & \multirow[t]{2}{*}{$1979-98$} & \multirow[b]{2}{*}{$1979-84$} & \multirow[b]{2}{*}{ 1985-91 } & \multirow[b]{2}{*}{$1992-98$} \\
\hline & & & $1953-58$ & 1959-65 & $1966-78$ & & & & \\
\hline \multicolumn{10}{|l|}{ Metropolis } \\
\hline Shanghai & 5.7 & 3.4 & 5.1 & -4.3 & 6.4 & 8.2 & 6.6 & 5.5 & 12.7 \\
\hline Beijing & 5.8 & 3.0 & 7.3 & -5.9 & 8.1 & 8.0 & 7.8 & 6.5 & 9.3 \\
\hline Tianjin & 5.5 & 3.8 & 7.5 & -5.0 & 5.8 & 7.5 & 6.3 & 4.4 & 11.9 \\
\hline \multicolumn{10}{|l|}{ Northeast } \\
\hline Jilin & 4.0 & 0.8 & 0.8 & -3.0 & 1.8 & 8.3 & 8.5 & 6.5 & 10.0 \\
\hline Liaoning & 4.9 & 2.6 & 7.4 & -7.6 & 5.5 & 7.8 & 6.2 & 6.6 & 8.9 \\
\hline Heilongjiang & 3.5 & 1.0 & 5.3 & -7.9 & 2.4 & 6.3 & 5.7 & 5.5 & 7.9 \\
\hline \multicolumn{10}{|l|}{ Coast } \\
\hline Guangdong & 5.4 & 1.5 & 4.5 & 0.8 & 1.7 & 11.5 & 8.9 & 11.0 & 12.2 \\
\hline Fujian & 5.1 & 0.9 & 5.2 & -2.2 & 1.6 & 10.8 & 9.8 & 7.9 & 14.6 \\
\hline Zhejiang & 5.5 & 1.5 & 3.3 & -0.1 & 2.3 & 10.5 & 9.7 & 6.6 & 13.8 \\
\hline Jiangsu & 5.9 & 2.3 & 0.5 & 1.6 & 3.6 & 10.3 & 8.6 & 7.6 & 13.5 \\
\hline Hainan & & & & & & 10.0 & 9.0 & 7.7 & 9.0 \\
\hline Shandong & 5.9 & 2.5 & 3.3 & -2.0 & 4.0 & 10.0 & 10.0 & 6.5 & 13.0 \\
\hline Hebei & 4.5 & 1.2 & 1.4 & -5.5 & 2.9 & 8.4 & 6.1 & 6.0 & 12.1 \\
\hline \multicolumn{10}{|l|}{ Central } \\
\hline Henan & 4.9 & 1.8 & 3.1 & -4.9 & 2.8 & 8.4 & 9.2 & 5.7 & 11.5 \\
\hline Hubei & 4.4 & 1.4 & 8.1 & -2.1 & 2.0 & 8.1 & 7.7 & 5.0 & 11.6 \\
\hline Anhui & 4.0 & 1.6 & 4.3 & -1.0 & 1.6 & 8.0 & 8.6 & 3.4 & 13.3 \\
\hline Jiangxi & 3.5 & 0.8 & 3.8 & -3.0 & 0.4 & 8.0 & 6.6 & 6.0 & 11.3 \\
\hline Hunan & 4.0 & 1.5 & 5.7 & -3.8 & 2.3 & 7.0 & 5.8 & 5.0 & 9.8 \\
\hline Shanxi & 3.9 & 1.4 & 6.2 & -4.0 & 2.1 & 6.9 & 7.8 & 3.8 & 9.1 \\
\hline \multicolumn{10}{|l|}{ Northwest } \\
\hline Xinjiang & 4.1 & 0.2 & 7.4 & -1.8 & -0.6 & 8.7 & 8.5 & 8.0 & 7.5 \\
\hline Inner Mongolia & 3.9 & 0.7 & 7.7 & -5.3 & 1.9 & 7.8 & 8.5 & 6.0 & 8.7 \\
\hline Shaanxi & 4.6 & 1.9 & 6.8 & -3.9 & 3.0 & 7.8 & 7.4 & 7.4 & 7.7 \\
\hline Gansu & 4.5 & 2.2 & 5.6 & -2.4 & 5.3 & 7.4 & 3.8 & 7.4 & 8.4 \\
\hline Ningxia & 4.3 & 2.8 & 5.2 & 0.5 & 3.1 & 6.5 & 6.2 & 5.6 & 6.8 \\
\hline Qinghai & 3.6 & 2.6 & 7.1 & 3.0 & 2.2 & 5.3 & 5.9 & 3.5 & 6.4 \\
\hline \multicolumn{10}{|l|}{ Southwest } \\
\hline Yunnan & 4.4 & 1.7 & 5.9 & 0.7 & 2.0 & 8.0 & 7.7 & 7.3 & 8.8 \\
\hline Sichuan & 4.3 & 0.6 & 5.3 & -0.4 & 1.0 & 7.5 & 6.3 & 5.4 & 9.2 \\
\hline Guangxi & 4.5 & 2.6 & 7.1 & -1.4 & 4.2 & 7.2 & 6.2 & 4.5 & 10.3 \\
\hline Guizhou & 3.1 & -0.4 & 6.5 & -3.5 & 0.1 & 6.5 & 8.6 & 4.6 & 6.5 \\
\hline
\end{tabular}

Note: GDP per capita is measured at 1995 constant prices. Annual growth rates are calculated by regressing the logarithm of per capita GDP on a time trend. Tibet is not included due to missing data for GDP components. Sources: See Figure 1. 
Table 6. Ranking of Chinese provinces by GDP per capita

\begin{tabular}{|c|c|c|c|c|c|c|c|c|c|}
\hline \multirow[t]{2}{*}{ Province } & \multicolumn{9}{|c|}{ Rank in GDP per capita level (constant price 1995) } \\
\hline & 1952 & 1958 & 1965 & 1978 & 1952-78 shift & 1984 & 1991 & 1998 & 1978-98 shift \\
\hline Shanghai & 1 & 1 & 1 & 1 & 0 & 1 & 1 & 1 & 0 \\
\hline Beijing & 9 & 5 & 4 & 2 & 7 & 2 & 2 & 2 & 0 \\
\hline Tianjin & 4 & 3 & 2 & 3 & 1 & 3 & 3 & 3 & 0 \\
\hline Zhejiang & 7 & 11 & 9 & 7 & 0 & 6 & 6 & 4 & 3 \\
\hline Guangdong & 8 & 9 & 8 & 9 & -1 & 8 & 5 & 5 & 4 \\
\hline Jiangsu & 12 & 22 & 16 & 8 & 4 & 7 & 8 & 6 & 2 \\
\hline Fujian & 11 & 13 & 12 & 16 & -5 & 10 & 10 & 7 & 9 \\
\hline Liaoning & 5 & 4 & 7 & 5 & 0 & 4 & 4 & 8 & -3 \\
\hline Shandong & 22 & 24 & 24 & 17 & 5 & 11 & 11 & 9 & 8 \\
\hline Heilongjiang & 2 & 2 & 3 & 4 & -2 & 5 & 7 & 10 & -6 \\
\hline Hebei & 6 & 16 & 19 & 11 & -5 & 16 & 15 & 11 & 0 \\
\hline Hainan & & & & 21 & & 19 & 13 & 12 & 9 \\
\hline Xinjiang & 10 & 6 & 5 & 14 & -4 & 13 & 9 & 13 & 1 \\
\hline Jilin & 3 & 10 & 10 & 10 & -7 & 12 & 12 & 14 & -4 \\
\hline Hubei & 18 & 12 & 15 & 18 & 0 & 15 & 18 & 15 & 3 \\
\hline Inner Mongolia & 15 & 7 & 13 & 19 & -4 & 18 & 16 & 16 & 3 \\
\hline Shanxi & 17 & 8 & 11 & 13 & 4 & 14 & 19 & 17 & -4 \\
\hline Hunan & 13 & 15 & 18 & 15 & -2 & 20 & 20 & 18 & -3 \\
\hline Anhui & 19 & 18 & 17 & 23 & -3 & 21 & 27 & 19 & 4 \\
\hline Henan & 23 & 26 & 27 & 26 & -2 & 24 & 24 & 20 & 6 \\
\hline Qinghai & 16 & 14 & 6 & 6 & 10 & 9 & 14 & 21 & -15 \\
\hline Ningxia & 20 & 19 & 14 & 12 & 8 & 17 & 17 & 22 & -10 \\
\hline Guangxi & 25 & 23 & 23 & 20 & 5 & 23 & 25 & 23 & -3 \\
\hline Jiangxi & 14 & 17 & 20 & 25 & -10 & 27 & 26 & 24 & 1 \\
\hline Sichuan & 21 & 20 & 21 & 22 & 0 & 22 & 21 & 25 & -3 \\
\hline Yunnan & 26 & 27 & 22 & 24 & 3 & 25 & 22 & 26 & -2 \\
\hline Shaanxi & 27 & 25 & 26 & 27 & 1 & 26 & 23 & 27 & 0 \\
\hline Gansu & 28 & 28 & 28 & 28 & 1 & 29 & 28 & 28 & 0 \\
\hline Guizhou & 24 & 21 & 25 & 29 & -4 & 28 & 29 & 29 & 0 \\
\hline
\end{tabular}

Note: The 1952-78 shifts are calculated without taking Hainan into consideration. Tibet is not included due to missing data for GDP components.

Sources: See Figure 1. 
Table 7. Gaps between the top-5 and bottom-5 provinces in GDP per capita

\begin{tabular}{lccccccc}
\hline GDP per capita level & $\mathbf{1 9 5 2}$ & $\mathbf{1 9 5 8}$ & $\mathbf{1 9 6 5}$ & $\mathbf{1 9 7 8}$ & $\mathbf{1 9 8 5}$ & $\mathbf{1 9 9 2}$ & $\mathbf{1 9 9 8}$ \\
\hline & & & & & & & \\
Top-5 & 1,028 & 1,650 & 1,445 & 2,500 & 3,797 & 5,607 & 12,759 \\
Bottom-5 & 403 & 583 & 543 & 746 & 1,157 & 1,770 & 3,557 \\
National mean & 616 & 838 & 780 & 1,143 & 1,849 & 2,929 & 6,400 \\
& & & & & & & \\
Absolute income gap & 625 & 1,067 & 901 & 1,754 & 2,641 & 3,837 & 9,202 \\
Relative income gap & 1.01 & 1.27 & 1.16 & 1.54 & 1.43 & 1.31 & 1.44 \\
Income ratio, Top-5/Bottom-5 & 2.55 & 2.83 & 2.66 & 3.35 & 3.28 & 3.17 & 3.59 \\
\hline
\end{tabular}

Note: GDP per capita is measured at 1995 constant prices by summing up the sectoral components. The average GDP per capita level is computed as the weighted sum of per capita provincial GDP levels, the weights being the provincial share in total population of the group (top-5, bottom-5 or all provinces). Top-5 are the five richest provinces in a particular year and bottom- 5 are the five poorest provinces in a particular year. The relative gap is the difference between the top- 5 and bottom- 5 divided by the national mean.

Sources: See Figure 1. 
Table 8. Agricultural share of employment and GDP in selected provinces

\section{Share of employment, \%}

\begin{tabular}{|c|c|c|c|c|c|c|}
\hline & $\underline{1978}$ & $\underline{1988}$ & $\underline{1998}$ & $\underline{1978}$ & $\underline{1988}$ & $\underline{1998}$ \\
\hline National & 70.5 & 59.4 & 49.8 & 41.3 & 28.2 & 17.4 \\
\hline \multicolumn{7}{|l|}{ Northeast } \\
\hline$\overline{\text { Liaoning }}$ & 47.5 & 33.6 & 33.6 & 25.2 & 17.0 & 14.1 \\
\hline Heilongjiang & 52.6 & 38.5 & 48.6 & 28.2 & 20.1 & 17.4 \\
\hline \multicolumn{7}{|l|}{ Coast } \\
\hline Guangdong & 73.7 & 53.7 & 41.1 & 46.5 & 29.2 & 12.9 \\
\hline Zhejiang & 73.6 & 51.2 & 42.4 & 55.6 & 28.7 & 13.1 \\
\hline \multicolumn{7}{|l|}{ Central } \\
\hline Henan & 80.6 & 67.6 & 58.9 & 53.8 & 35.5 & 23.8 \\
\hline Anhui & 81.7 & 68.5 & 59.4 & 64.1 & 44.3 & 25.3 \\
\hline \multicolumn{7}{|l|}{ Northwest } \\
\hline Shaanxi & 71.1 & 63.6 & 59.0 & 42.2 & 26.9 & 20.9 \\
\hline Gansu & 76.9 & 67.7 & 59.9 & 28.4 & 25.7 & 17.1 \\
\hline \multicolumn{7}{|l|}{ Southwest } \\
\hline Sichuan & 81.8 & 73.0 & 62.3 & 59.2 & 39.6 & 24.2 \\
\hline Guizhou & 82.8 & 78.1 & 69.7 & 57.9 & 43.6 & 31.0 \\
\hline
\end{tabular}

Notes: For Gansu, employment in agricultural sector was available only from 1983 onward. In 1983, the rural share of employment was 80.2 while the agricultural share was 80.2. 1978 figure for Gansu is rural share of employment.

Sources: NBS (1999a).

Share of GDP (1995 prices), \% 
Table 9. Summary of regressions results of GDP per capita in benchmark years on topographic characteristics

\begin{tabular}{|c|c|c|c|}
\hline Variables & Impact & Robustness & Without metropolises \\
\hline $\begin{array}{l}1952 \\
\text { Distance from the coast } \\
\text { Pop } 100 \mathrm{cr} \\
\text { Popl00km } \\
\text { Slope over 10\% } \\
\text { Average slope } \\
\text { Average elevation } \\
1978 \\
\text { Distance from the coast } \\
\text { Pop100cr } \\
\text { Poplo0km } \\
\text { Slope over } 10 \% \\
\text { Average slope } \\
\text { Average elevation } \\
\text { 1998 } \\
\text { Distance from the coast } \\
\text { Pop } 100 \mathrm{cr} \\
\text { Poplo0km } \\
\text { Slope over } 10 \% \\
\text { Average slope } \\
\text { Average elevation }\end{array}$ & $\begin{array}{c}+ \\
\text { Never significant } \\
+ \\
- \\
- \\
\text { Never significant } \\
\\
+ \\
\text { Never significant } \\
+ \\
- \\
- \\
\text { Non significant } \\
\\
+ \\
+ \\
+ \\
- \\
- \\
\text { Never significant }\end{array}$ & $\begin{array}{l}\text { Around 10\% } \\
\text { 5-10\% } \\
\text { Around 5\% } \\
\text { Always 5\% level } \\
\\
\text { Strongly significant } \\
\text { Strongly significant } \\
\text { Strongly significant } \\
\text { Around 5\% } \\
\text { Variable }\end{array}$ & $\begin{array}{l}\text { No change } \\
\text { No change } \\
\text { Less significant } \\
\text { No change } \\
\text { Less significant } \\
\text { No change } \\
\\
\text { Less significant } \\
\text { No change } \\
\text { No change } \\
\text { Less significant } \\
\text { No change } \\
\text { Better results }\end{array}$ \\
\hline
\end{tabular}




\section{Table 10. Selected growth-related regressions from the literature}

(constant term omitted, brackets contain absolute t-statistics)

Jian, Sachs and Warner (1996): Explaining Regional Growth, cross section

(dependent variable is average annual provincial GDP growth rate, 1978-93)

$$
\begin{gathered}
\text { Initial Initial share Coast dummy } \\
\text { GDP of agriculture }
\end{gathered}
$$

$\begin{array}{cccc}\text { Eq } 1 & -0.017 & & \\ & {[3.32]} & & \\ & & & \\ \text { Eq } 2 & -0.009 & 0.08 & 0.021 \\ & {[1.11]} & {[1.88]} & {[3.93]}\end{array}$

Wang and Hu (1999): Explaining foreign investment flows into provinces, cross section (dependent variable is accumulated foreign capital over 1983-95)

$\begin{array}{lccccc} & \text { GDP 1991 } & \begin{array}{c}\text { Growth in } \\ \mathbf{1 9 7 8 - 9 1}\end{array} & \begin{array}{c}\text { Infrastructure } \\ \text { in 1990 }\end{array} & \begin{array}{c}\text { Illiteracy in } \\ \mathbf{1 9 9 0}\end{array} & \begin{array}{c}\text { Preferential } \\ \text { Policy }\end{array} \\ & & & & & \\ \text { Economic Model } & 0.383 & 0.348 & 0.292 & 0.037 & \\ \text { Eq 3 } & {[2.26]} & {[2.26]} & {[1.71]} & {[0.23]} & \\ & & & & & \\ \text { Political Economy Model } & 0.239 & 0.023 & -0.208 & 0.025 & 0.858 \\ \text { Eq 4 } & {[2.09]} & {[0.20]} & {[1.48]} & {[0.24]} & {[5.83]}\end{array}$

Bao, Chang, Sachs and Woo (forthcoming): Explaining provincial growth, cross section (dependent variable is average annual provincial GDP growth rate, 1978-97)

GDP 1978 Inverse distance Coastline length Pop100km Elevation

$\begin{array}{lccccc}\text { Eq 5 } & -0.178 & 375.02 & & 245.57 & \\ & {[2.88]} & {[1.76]} & & {[3.91]} & \\ \text { Eq 6 } & -0.178 & 361.5 & & 209.87 & -0.023 \\ & {[2.88]} & {[1.69]} & & {[2.82]} & {[.90]} \\ \text { Eq 7 } & & & & \\ & -0.063 & & 0.098 & 113.19 & -0.020 \\ & {[1.53]} & & {[4.89]} & {[1.88]} & {[1.06]}\end{array}$

Zhang (forthcoming): Explaining provincial growth, cross section

\begin{tabular}{|c|c|c|c|c|c|c|}
\hline & $\begin{array}{l}\text { Initial } \\
\text { GDP }\end{array}$ & $\begin{array}{l}\text { Non-state } \\
\text { sector size }\end{array}$ & Export/GDP & $\begin{array}{c}\text { Foreign invest } \\
\text { / total invest }\end{array}$ & $\begin{array}{l}\text { Coastal } \\
\text { dummy }\end{array}$ & $\begin{array}{l}\text { Western } \\
\text { dummy }\end{array}$ \\
\hline $\begin{array}{l}\text { 1978-84 } \\
\text { Eq } 8\end{array}$ & $\begin{array}{l}-0.03 \\
{[5.36]}\end{array}$ & $\begin{array}{l}0.025 \\
{[1.16]}\end{array}$ & $\begin{array}{l}0.612 \\
{[0.65]}\end{array}$ & & $\begin{array}{l}0.012 \\
{[1.48]}\end{array}$ & $\begin{array}{c}-0.013 \\
{[1.81]}\end{array}$ \\
\hline $\begin{array}{l}\mathbf{1 9 8 5 - 9 5} \\
\text { Eq } 9\end{array}$ & $\begin{array}{l}-0.027 \\
{[7.42]}\end{array}$ & $\begin{array}{l}0.009 \\
{[2.15]}\end{array}$ & $\begin{array}{l}0.809 \\
{[4.47]}\end{array}$ & & $\begin{array}{l}0.031 \\
{[6.96]}\end{array}$ & $\begin{array}{c}-0.009 \\
{[1.44]}\end{array}$ \\
\hline $\begin{array}{l}\text { 1985-95 } \\
\text { Eq } 10\end{array}$ & $\begin{array}{l}-0.028 \\
{[7.70]}\end{array}$ & $\begin{array}{l}0.092 \\
{[1.25]}\end{array}$ & & $\begin{array}{l}0.094 \\
{[4.09]}\end{array}$ & $\begin{array}{l}0.025 \\
{[4.07]}\end{array}$ & $\begin{array}{l}-0.008 \\
{[1.34]}\end{array}$ \\
\hline
\end{tabular}

(dependent variable is average annual provincial GDP growth rate of subperiods, 1978-84 and 1985-95) 
Table 11. Preferential policy index

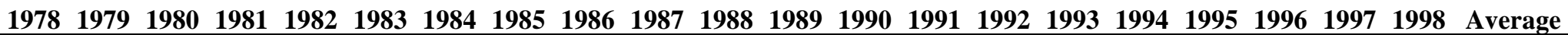

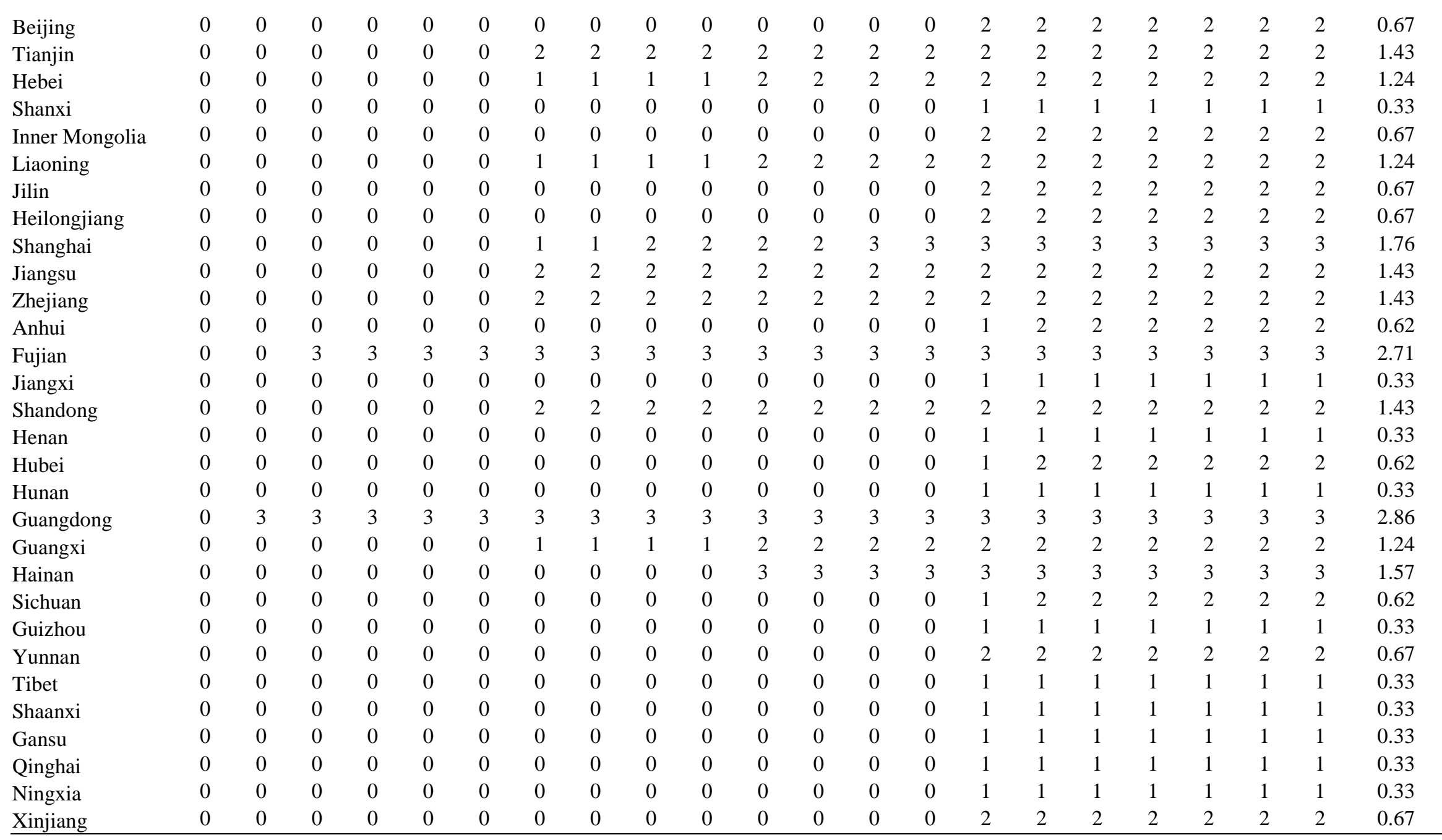




\section{Table 12. Initial disentangling of geography and policy, cross-section regressions}

\section{Initial Coast \\ $\underline{\text { Period GDPlevel }} \underline{\underline{\text { dummy }}} \underline{\text { Pop100cr }} \underline{\text { Policy }} \quad \underline{R^{2}}$}

Part A: Subperiod averaged

\begin{tabular}{lcccccc}
\hline Eq 1 & $1979-84$ & -0.0133 & 0.0173 & & \\
& & 1.55 & 2.98 & & \\
& & & & \\
Eq 2 & $1985-91$ & 0.0002 & 0.0223 & & & \\
& & 0.02 & 3.09 & & & \\
& & & & \\
Eq 3 & $1992-98$ & -0.0025 & 0.0387 & & & \\
& & 0.20 & 5.11 & & & \\
& & & & & \\
Eq 4 & $1979-84$ & -0.0123 & & 0.0151 & 0.0056 & \\
& & 1.47 & & 2.31 & 2.88 & 0.28 \\
Eq 5 & $1985-91$ & -0.0034 & & -0.0064 & 0.0119 & \\
& & 0.29 & & 0.73 & 2.67 & 0.38 \\
Eq 6 & $1992-98$ & -0.0060 & & 0.0427 & 0.0099 & \\
& & 0.57 & & 7.14 & 1.35 & 0.71
\end{tabular}

Part B: Entire period averaged

\begin{tabular}{lcccccc}
\hline Eq 7 & $1979-98$ & -0.0082 & 0.0267 & & & \\
& & 1.14 & 5.92 & & & \\
& & & & & \\
Eq 8 & $1979-98$ & -0.0122 & & 0.0145 & 0.0136 & \\
& & 2.18 & & 3.51 & 8.37 & 0.77
\end{tabular}

Part C: Characteristics of preferential policy and geography variables

\begin{tabular}{llcccc} 
& & National & Northeast & Coast & Central \\
Pop100cr & Mean & 0.379 & 0.176 & 0.818 & 0.574 \\
& Standard deviation & 0.406 & 0.285 & 0.175 & 0.382 \\
& Coefficient of variation & 1.071 & 1.620 & 0.214 & 0.666 \\
& & & & & \\
\multirow{3}{*}{ Policy } & Mean & $1979-83$ & $1984-91$ & $1992-98$ & $1979-98$ \\
& Standard deviation & 0.231 & 0.709 & 1.753 & 0.897 \\
& Coefficient of variation & 0.636 & 1.045 & 0.647 & 0.697 \\
& 2.758 & 1.474 & 0.369 & 0.777
\end{tabular}

Notes: Dependent variable is the average growth rate of per capita GDP of province in indicated period. Constant term not reported, absolute t-statistic in italic. Chongqing data are included into Sichuan. N=26, Tibet (missing data), Beijing, Shanghai, and Tianjin are omitted.

Pop100cr = proportion of the provincial population in 1994 living within 100 kilometers of coast and navigable rivers that flow into the sea. Policy = degree of exemption from regulations governing FDI, trade and taxation (extent of preferential treatment received by the province). 
Table 13. Cross-section growth regressions with structural variables

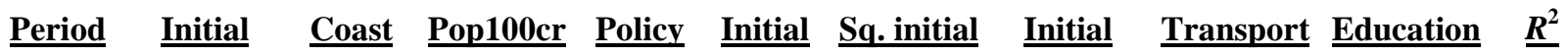 \\ GDP level \\ Agricul. Agricul. SOE size
}

\title{
Subperiod averaged
}

\begin{tabular}{|c|c|c|c|c|c|c|c|c|c|c|c|}
\hline Eq 1 & $1979-84$ & $\begin{array}{c}-0.0099 \\
0.61\end{array}$ & $\begin{array}{c}0.0084 \\
1.35\end{array}$ & & & $\begin{array}{c}0.1095 \\
0.51\end{array}$ & $\begin{array}{c}-0.1097 \\
0.41\end{array}$ & $\begin{array}{c}-0.0830 \\
2.31\end{array}$ & & & 0.46 \\
\hline Eq 2 & $1985-91$ & $\begin{array}{c}-0.0109 \\
0.55\end{array}$ & $\begin{array}{c}0.0224 \\
2.57\end{array}$ & & & $\begin{array}{c}0.2241 \\
0.88\end{array}$ & $\begin{array}{c}-0.3379 \\
0.94\end{array}$ & $\begin{array}{c}0.0487 \\
0.87\end{array}$ & & & 0.39 \\
\hline Eq 3 & $1992-98$ & $\begin{array}{c}-0.0065 \\
0.50\end{array}$ & $\begin{array}{c}0.0290 \\
4.40\end{array}$ & & & $\begin{array}{c}0.3493 \\
0.78\end{array}$ & $\begin{array}{c}-0.4466 \\
0.51\end{array}$ & $\begin{array}{c}-0.1990 \\
6.15\end{array}$ & & & 0.79 \\
\hline Eq 4 & $1979-84$ & $\begin{array}{c}-0.0086 \\
0.52\end{array}$ & & $\begin{array}{c}0.0034 \\
0.39\end{array}$ & $\begin{array}{c}0.0033 \\
1.53\end{array}$ & $\begin{array}{c}0.1165 \\
0.52\end{array}$ & $\begin{array}{c}-0.1170 \\
0.39\end{array}$ & $\begin{array}{c}-0.0849 \\
2.21\end{array}$ & & & 0.44 \\
\hline Eq 5 & $1985-91$ & $\begin{array}{c}0.0108 \\
0.56\end{array}$ & & $\begin{array}{c}-0.0027 \\
0.24\end{array}$ & $\begin{array}{c}0.0116 \\
2.54\end{array}$ & $\begin{array}{c}0.3477 \\
1.68\end{array}$ & $\begin{array}{c}-0.5057 \\
1.54\end{array}$ & $\begin{array}{c}0.0575 \\
0.99\end{array}$ & & & 0.47 \\
\hline Eq 6 & $1992-98$ & $\begin{array}{c}-0.0211 \\
1.65\end{array}$ & & $\begin{array}{c}0.0328 \\
6.00\end{array}$ & $\begin{array}{c}0.0111 \\
2.20\end{array}$ & $\begin{array}{c}0.3572 \\
0.88\end{array}$ & $\begin{array}{c}-0.7079 \\
0.93\end{array}$ & $\begin{array}{c}-0.1415 \\
4.62\end{array}$ & & & 0.84 \\
\hline Eq 7 & 1979-84 & $\begin{array}{c}-0.0268 \\
1.46\end{array}$ & & $\begin{array}{c}0.0088 \\
0.64\end{array}$ & $\begin{array}{c}0.0053 \\
1.66\end{array}$ & $\begin{array}{c}0.2599 \\
1.32\end{array}$ & $\begin{array}{c}-0.3618 \\
1.38\end{array}$ & $\begin{array}{c}-0.1204 \\
2.53\end{array}$ & $\begin{array}{c}-0.0469 \\
0.82\end{array}$ & $\begin{array}{c}0.1058 \\
2.10\end{array}$ & 0.55 \\
\hline Eq 8 & $1985-91$ & $\begin{array}{c}-0.0009 \\
0.04\end{array}$ & & $\begin{array}{c}-0.0060 \\
0.41\end{array}$ & $\begin{array}{c}0.0116 \\
2.12\end{array}$ & $\begin{array}{c}0.5936 \\
2.24\end{array}$ & $\begin{array}{c}-0.8873 \\
2.04\end{array}$ & $\begin{array}{c}0.0554 \\
0.95\end{array}$ & $\begin{array}{c}0.0212 \\
0.48\end{array}$ & $\begin{array}{c}0.0925 \\
0.98\end{array}$ & 0.53 \\
\hline Eq 9 & $1992-98$ & $\begin{array}{c}-0.0237 \\
1.87\end{array}$ & & $\begin{array}{c}0.0286 \\
2.47\end{array}$ & $\begin{array}{c}0.0140 \\
2.09\end{array}$ & $\begin{array}{c}0.4221 \\
1.10\end{array}$ & $\begin{array}{c}-0.8323 \\
1.15\end{array}$ & $\begin{array}{c}-0.0587 \\
0.98\end{array}$ & $\begin{array}{c}0.0566 \\
1.82\end{array}$ & $\begin{array}{c}0.0325 \\
0.74\end{array}$ & 0.87 \\
\hline
\end{tabular}

\section{Entire period averaged}

Eq $10 \quad 1979-98 \quad-0.0058 \quad 0.0201$

\begin{tabular}{|c|c|c|c|c|c|c|c|}
\hline & & $\begin{array}{c}0.0935 \\
0.74\end{array}$ & $\begin{array}{c}-0.1013 \\
0.59\end{array}$ & $\begin{array}{c}-0.0615 \\
2.12\end{array}$ & & & 0.76 \\
\hline 0.0131 & 0.0117 & 0.1716 & -0.2560 & -0.0316 & & & \\
\hline 2.94 & 5.97 & 1.72 & 1.82 & 1.13 & & & 0.83 \\
\hline 0.0143 & 0.0128 & 0.2295 & -0.3413 & -0.0318 & -0.0030 & 0.0812 & \\
\hline & 5.15 & 3.70 & 3.59 & 0.94 & 0.13 & 2.27 & 0.89 \\
\hline
\end{tabular}

Notes: Dependent variable is the average growth rate of per capita GDP of province in indicated period. Constant term not reported, absolute t-statistic in italic. Chongqing data are included into Sichuan.

For equations 1 to 6, 10 and 11; N=26, Tibet (missing data), Beijing, Shanghai, and Tianjin are omitted.

For Equations 7, 8, 9 and 12; N=25; Tibet (missing data), Hainan (missing data), Beijing, Shanghai, and Tianjin are omitted. 
Table 14. The key growth mechanisms of the policy and geography variables

Part A: Degree of correlation among Pop100cr, Policy and FDI for different periods

\begin{tabular}{|c|c|c|c|c|}
\hline & FDI & Policy & FDI & Policy \\
\hline Policy & $\begin{array}{r}19 \\
0.8226 \\
0.000\end{array}$ & & $\begin{array}{c}19 \\
0.6568 \\
0.003\end{array}$ & \\
\hline Pop100cr & $\begin{array}{c}0.2292 \\
0.260\end{array}$ & $\begin{array}{c}0.3131 \\
0.119\end{array}$ & $\begin{array}{c}0.4101 \\
0.037\end{array}$ & $\begin{array}{c}0.6036 \\
0.001\end{array}$ \\
\hline Policy & $\begin{array}{r}19 \\
0.7529 \\
0.000\end{array}$ & & $\begin{array}{c}19 \\
0.8119 \\
0.000\end{array}$ & \\
\hline Pop100cr & $\begin{array}{c}0.5528 \\
0.003\end{array}$ & $\begin{array}{c}0.4509 \\
0.021\end{array}$ & $\begin{array}{l}0.527 \\
0.006\end{array}$ & $\begin{array}{c}0.5362 \\
0.005\end{array}$ \\
\hline
\end{tabular}

Part B: Foreign direct investments concentrate in regions where rural enterprises bloom

Average provincial share of employment and investment within each region in 1999

Location of province
Total
SOE
FDI
Rural
enterprises

Average provincial share of employment

$\begin{array}{lcccc}\text { Northeast } & 2.5 & 4.9 & 3.1 & 2.4 \\ \text { Coast } & 4.7 & 4.3 & 10.7 & 6.5 \\ \text { Central } & 4.9 & 4.5 & 1.4 & 4.7 \\ \text { Northwest } & 1.4 & 2.1 & 0.4 & 1.4 \\ \text { Southwest } & 5.3 & 3.8 & 1.2 & 2.8\end{array}$

$\underline{\text { Average provincial share of investment }}$

$\begin{array}{lcccc}\text { Northeast } & 3.1 & 3.9 & 2.0 & 1.7 \\ \text { Coast } & 7.1 & 6.0 & 10.3 & 8.2 \\ \text { Central } & 3.3 & 3.5 & 2.0 & 3.4 \\ \text { Northwest } & 1.4 & 1.8 & 0.3 & 0.8 \\ \text { Southwest } & 3.3 & 3.6 & 1.8 & 2.9\end{array}$

Notes: Italicized number in Part A refers to the significance level at which the correlation is different from zero. Part B excludes Beijing, Shanghai, Tianjin, and Tibet. Chongqing data are included inside Sichuan. 
Table 15. Addition of FDI tends to reduce significance of policy and geography variables

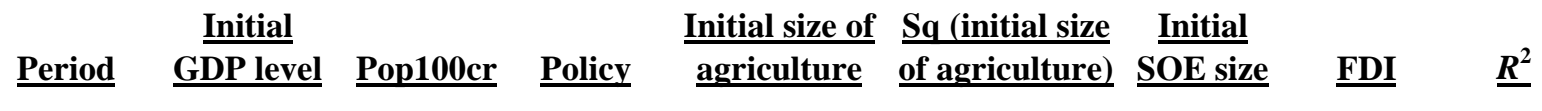

\begin{tabular}{|c|c|c|c|c|c|c|c|c|}
\hline Eq 1 & 1979-84 & $\begin{array}{c}-0.0086 \\
0.51\end{array}$ & $\begin{array}{c}0.0034 \\
0.38\end{array}$ & $\begin{array}{c}0.0036 \\
1.17\end{array}$ & $\begin{array}{c}0.1152 \\
0.49\end{array}$ & $\begin{array}{c}-0.1151 \\
0.37\end{array}$ & $\begin{array}{c}-0.0844 \\
2.12\end{array}$ & $\begin{array}{c}-0.1215 \\
0.17\end{array}$ \\
\hline Eq 2 & $1985-91$ & $\begin{array}{c}0.0072 \\
0.34\end{array}$ & $\begin{array}{c}-0.0041 \\
0.46\end{array}$ & $\begin{array}{c}0.0038 \\
0.95\end{array}$ & $\begin{array}{c}0.4943 \\
2.07\end{array}$ & $\begin{array}{c}-0.7623 \\
2.21\end{array}$ & $\begin{array}{c}0.0079 \\
0.13\end{array}$ & $\begin{array}{c}1.0530 \\
3.46\end{array}$ \\
\hline Eq 3 & $1992-98$ & $\begin{array}{c}-0.0209 \\
1.56\end{array}$ & $\begin{array}{c}0.0319 \\
4.04\end{array}$ & $\begin{array}{c}0.0101 \\
1.39\end{array}$ & $\begin{array}{c}0.3674 \\
0.88\end{array}$ & $\begin{array}{c}-0.7227 \\
0.92\end{array}$ & $\begin{array}{c}-0.1454 \\
3.61\end{array}$ & $\begin{array}{c}0.0179 \\
0.22\end{array}$ \\
\hline Eq 4 & 1979-98 & $\begin{array}{c}-0.0115 \\
1.41\end{array}$ & $\begin{array}{c}0.0125 \\
2.84\end{array}$ & $\begin{array}{c}0.0101 \\
1.88\end{array}$ & $\begin{array}{c}0.1904 \\
1.96\end{array}$ & $\begin{array}{c}-0.2861 \\
2.06\end{array}$ & $\begin{array}{c}-0.0360 \\
1.05\end{array}$ & $\begin{array}{c}0.0665 \\
0.41\end{array}$ \\
\hline
\end{tabular}

Notes: Dependent variable is the average growth rate of per capita GDP of province in indicated period.

Constant term not reported, absolute t-statistic in italic. Chongqing data included into Sichuan.

$\mathrm{N}=26$, Tibet (missing data), Beijing, Shanghai, and Tianjin are omitted 
Table 16. Growth in the recent period, 1996-99

\section{Part A: Caught up and still growing faster}

\begin{tabular}{|c|c|c|c|c|c|c|c|c|}
\hline & \multirow[b]{2}{*}{$\begin{array}{l}\text { Income Rank } \\
\text { in } 1978\end{array}$} & \multirow[b]{2}{*}{$\begin{array}{c}\text { Income Rank } \\
\text { in } 1998\end{array}$} & \multirow{2}{*}{$\begin{array}{c}\text { Per Capita } \\
\text { GDP in } 1995 \\
\text { (current prices) }\end{array}$} & \multicolumn{4}{|c|}{ Growth rate of GDP per capita } & \multirow[b]{2}{*}{$\begin{array}{l}\text { Average } \\
1996-99\end{array}$} \\
\hline & & & & 1996 & 1997 & 1998 & 1999 & \\
\hline \multicolumn{9}{|c|}{ Northeastren Region } \\
\hline Heilongiiang & 4 & 10 & 5,465 & 9.9 & 9.4 & 7.7 & 6.8 & 8.4 \\
\hline Liaoning & 5 & 8 & 6,880 & 8.1 & 8.4 & 7.8 & 7.8 & 8.0 \\
\hline \multicolumn{9}{|c|}{ Coastal Region } \\
\hline Zhejiang & 7 & 4 & 8,074 & 12.1 & 10.5 & 9.5 & 9.4 & 10.4 \\
\hline Guangdong & 9 & 5 & 8,494 & 9.1 & 9.0 & 8.6 & 7.9 & 8.7 \\
\hline Jiangsu & 8 & 6 & 7,299 & 11.7 & 11.5 & 10.5 & 9.6 & 10.8 \\
\hline Fujian & 16 & 7 & 6,787 & 14.4 & 13.5 & 10.4 & 9.0 & 11.8 \\
\hline
\end{tabular}

Part B: Actual and counterfactual growth scenarios for 1996-99 period

Geography Policy

Location of

province

Metropolis

Northeast

Coast

Central

Northwest

Southwest

Average of Regions
Average 1996-99 growth rate, \% effect

(in percentage points)
Sources: NBS (2000).

Notes: Part A: Income level is nominal, and income growth rate is real. GDP per capita growth rate $=$ GDP growth rate - population growth rate. Population growth rate assumed to be same as average annual growth in 1995-98.

Part B: Geography coefficient $=0.0347$ which is the average of Eq 6 in table 12, and Eq 6 and 9 in table 13.

Policy coefficient $=0.01167$ which is the average of Eq 6 in table 12, and Eq 6 and 9 in table 13.

Value of Policy variable is average value for 1996-98. Growth rate refers to GDP, not GDP per capita.

\section{Counterfactual annual growth rates, \%}

$\begin{array}{ll}\text { No policies to attract } & \text { Uniform policy toward } \\ \text { FDI, i.e. } \text { Policy=0 } & \text { FDI, i.e. } \text { Policy }=2\end{array}$

$\begin{array}{rr}6.38 & 8.72 \\ 6.86 & 9.19 \\ 7.88 & 10.22 \\ 8.73 & 11.06 \\ 7.76 & 10.09 \\ 7.05 & 9.39 \\ 7.44 & 9.78\end{array}$


Appendix Table. Pooled estimations with structural variables

\begin{tabular}{|c|c|c|c|c|c|c|c|c|c|c|c|}
\hline & $\underline{\text { Gnitial }}$ & $\underline{\text { Coast }}$ & Pop100cr & Policy & $\underline{\text { Initial }}$ & $\frac{\text { Sq. initial }}{\text { agricul. }}$ & $\underline{\underline{\text { Initial }}} \underline{\underline{\text { OE size }}}$ & $\underline{\text { Transport }}$ & $\underline{\text { Education }}$ & $\underline{\text { FDI }}$ & $\underline{R}^{2}$ \\
\hline Eq 1 & $\begin{array}{c}0.0181 \\
3.32\end{array}$ & & & & & & & & & & 0.15 \\
\hline Eq 2 & $\begin{array}{c}0.0135 \\
3.09\end{array}$ & $\begin{array}{c}0.0227 \\
3.85\end{array}$ & & & & & & & & & 0.29 \\
\hline Eq 3 & $\begin{array}{c}-0.0006 \\
0.09\end{array}$ & & $\begin{array}{c}0.0149 \\
2.24\end{array}$ & $\begin{array}{c}0.0129 \\
3.74\end{array}$ & & & & & & & 0.41 \\
\hline Eq 4 & $\begin{array}{c}0.0147 \\
2.16\end{array}$ & $\begin{array}{c}0.0216 \\
2.55\end{array}$ & & & $\begin{array}{c}-0.1529 \\
0.79\end{array}$ & $\begin{array}{c}0.2839 \\
0.95\end{array}$ & $\begin{array}{c}-0.0155 \\
0.33\end{array}$ & & & & 0.31 \\
\hline Eq 5 & $\begin{array}{c}-0.0050 \\
0.59\end{array}$ & & $\begin{array}{c}0.0143 \\
1.74\end{array}$ & $\begin{array}{c}0.0133 \\
3.88\end{array}$ & $\begin{array}{c}-0.1686 \\
0.95\end{array}$ & $\begin{array}{c}0.2349 \\
0.86\end{array}$ & $\begin{array}{c}-0.0064 \\
0.16\end{array}$ & & & & 0.41 \\
\hline Eq 6 & $\begin{array}{c}-0.0074 \\
0.76\end{array}$ & & $\begin{array}{c}0.0082 \\
0.75\end{array}$ & $\begin{array}{c}0.0126 \\
3.52\end{array}$ & $\begin{array}{c}-0.0791 \\
0.43\end{array}$ & $\begin{array}{c}0.1226 \\
0.43\end{array}$ & $\begin{array}{c}0.0340 \\
0.69\end{array}$ & $\begin{array}{c}0.0550 \\
1.49\end{array}$ & $\begin{array}{c}0.0587 \\
1.28\end{array}$ & & 0.44 \\
\hline Eq 7 & $\begin{array}{c}-0.0093 \\
1.11\end{array}$ & & $\begin{array}{c}0.0141 \\
1.81\end{array}$ & $\begin{array}{c}0.0087 \\
2.64\end{array}$ & $\begin{array}{c}-0.0064 \\
0.04\end{array}$ & $\begin{array}{c}-0.0268 \\
0.10\end{array}$ & $\begin{array}{c}0.0038 \\
0.10\end{array}$ & & & $\begin{array}{c}0.4432 \\
3.40\end{array}$ & 0.51 \\
\hline
\end{tabular}

Notes: Dependent variable is the average growth rate of per capita GDP of province in each of the 3 sub-period (a) 1979-84 (b) 1985-91 (c) 1992-98. Constant term not reported, absolute t-statistic in italic. Sample excludes Beijing, Tianjin, Shanghai, Hainan and Tibet. Chongqing data are included into Sichuan.

Preliminary tests (not reported here) have been performed to ensure that the pooled specification is to be preferred to any individual (fixed or random) effect specification. 